\title{
RIESGO Y VENTURA DE UN GRAN BIBLIÓGRAFO, ESTUDIOSO DEL SIGLO DE ORO. NUEVO PERFIL DE C. A. DE LA BARRERA.
}

JOSÉ LARA GARRIDO

Universidad de Málaga

T o han faltado juicios valorativos que, de forma continuada desde el momento mismo de su muerte, vinieran a encomiar las dimensiones y calidades de la labor de erudición biobibliográfica debida a Cayetano Alberto de La Barrera y Leirado. Valgan como expresivas de entre una nutrida serie tres de esas alabanzas, resaltadas por la particular intensidad o el emblemático significado de la relación que sus autores tuvieron con la persona o con la obra del erudito decimonónico. Desde el doble fuero de la "amistad" y los compartidos quehaceres como "compañero" en la Biblioteca Nacional, J. E. Hartzenbusch declaró en solemne recordatorio y homenaje que por sus obras La Barrera estaba considerado antes de su muerte "entre los principales bibliógrafos españoles contemporáneos"1. Como editor y adicionador de una de las más sólidas contribuciones de La Barrera a la historia literaria del Siglo de Oro, la revolucionaria biografía de Lope de Vega, el mismísimo M. Menéndez Pelayo tuvo ocasión de rendirle homenaje al aquilatar a fondo la excelencia del método aséptico y marcadamente positivista de ceñirse a los documentos

1 [J. E. Hartzenbusch], Memoria para la Biblioteca Nacional en el presente año, 1873, Madrid, 1873, p. 13. Estas memorias son documentos de excepcional interés y extremada rareza. Las comprendidas entre 1857 y 1876 forman colección en un volumen de la Biblioteca Nacional (INV 027 [460] NAC) por el que cito. 
José Lara Garrido

practicado en ella, declarando entonces a su autor "insigne erudito"2. Finalmente, como estudioso atento de su figura y conocedor privilegiado de la exhaustividad con la que indagaba y acopiaba materiales el discípulo y admirador de B. J. Gallardo, P. Sáinz Rodríguez ha venido en fechas relativamente cercanas a calificarlo de "uno de los hombres de más mérito del siglo XIX en el campo de la investigación literaria"3.

Hay que constatar, sin embargo, que estas muestras de lo que podría extenderse con las dimensiones de un coro prolongadamente repetitivo (aunque en bastantes ocasiones $\sin$ mayor conocimiento de causa $)^{4}$, no ha tenido

2 En las "Adiciones a la biografía de Lope de Vega Carpio compuesta por D. Cayetano Alberto de La Barrera", en Nueva biografía de Lope de Vega, II, Madrid, 19732, pp. 105-187. La cita corresponde a la p. 105." La biografía que acaba de leerse -indicaba el editor de Lope- es, sin disputa, una de las más extensas y completas que de ningún autor castellano pueden hallarse; pero como todos los trabajos de este género, no es ni puede ser definitivo. En los años que van transcurridos desde 1864 en que el Sr. La Barrera fechó su advertencia preliminar y presentó su libro al concurso de la Biblioteca Nacional, han aparecido algunos documentos nuevos de grande importancia [...] A llenar estos vacíos va encaminado el presente apéndice en que, ajustándonos estrictamente al método del Sr. La Barrera hemos dejado que los documentos hablen por sí, limitándonos a muy breves comentarios". Y el polígrafo se constriñó, como en ninguna otra ocasión, a un severo plan de ascético historicismo positivista, extractando, entre otras, las 147 cartas autógrafas de Lope que poseía el marqués de Pidal, o insertando las transcripciones de los 18 documentos encontrados por Asenjo Barbieri en el protocolo de Juan de Piña. Pero a decir verdad, Menéndez Pelayo tenía formado muy positivo juicio de La Barrera desde mucho antes. Ya en 1875, apenas transcurridos tres años del fallecimiento de aquél, lo calificó en su carta latina a Vito Fornari de "ardentissimo bibliophilo" (Epistolario, I, Madrid, 1982, p. 245). Con motivo de enjuiciar, tras una intensa familiaridad con esa obra y en general con los materiales de su autor sobre Lope, la Nueva biografía, subrayaba igualmente A. G. de Amezúa "la vastísima erudición de La Barrera [...] su juicio claro, reposado, sereno, enemigo, en general, de hipótesis, descubrimientos y conjeturas a que tan dados eran los investigadores literarios de su generación" (Lope de Vega en sus cartas, II, Madrid, 1940, p. 6).

3 P. Sáinz Rodríguez, Historia de la crítica literaria en España, Madrid, 1989, p. 212. Ahí mismo indica que tenía "grandes materiales reunidos para hacer su biografía y su crítica", aunque las entecas páginas dedicadas a La Barrera denotan un muy desigual laboreo del asunto. Hay que recordar, por estricta justicia distributiva, que en su conocido estudio sobre Gallardo, Sáinz Rodríguez aprovechó "los ricos materiales de La Barrera" y en la parte bibliográfica se limitó a transcribir el Catálogo elaborado por éste a lo largo de una vida de dedicación al tema "añadiendo tal cual noticia nueva" (A. Rodríguez Moñino, Don Bartolomé José Gallardo [1776-1852]. Estudio bibliográfico, Badajoz, 1955, p. 15).

4 Así en todos los panoramas de historia literaria. Valga de ejemplo el único que transmite datos de positivo interés sobre La Barrera, el de J. Cejador, en el cual queda calificado como "escritor muy erudito y uno de los nuestros más beneméritos historiadores literarios" (Historia de la lengua y literatura castellana, VIII, 1918, p. 300). Voces y ecos parecen concordes, con una significativa estridencia respecto al coro de alabanzas, la de D. Alonso, que en singular momento de exasperación calificó injustamente a La Barrera de "erudito atiborrado de noticias" (La "Epístola moral a Fabio" de Andrés Fernández de Andrada. Edición y estudio, Madrid, 1978, p. 95). Con menos vehemencia, y cuando no medió la ingenua inquina de quien tuvo que ver una y otra vez como 
Riesgo y ventura de un gran bibliógrafo...

refrendo a la hora de estudiar de modo acorde a la categoría de sus aportaciones la obra del bibliógrafo decimonónico. No sólo se echa en falta una más que merecida monografía sobre La Barrera, para la que disponemos de un nutrido material de variada índole (versiones primeras y posteriores enmiendas y adiciones de algunas de sus obras, un buen número de cartas) bien localizado y accesible. Ni siquiera contamos con cualquier variante menor, ya en forma de entrada en obras generales sobre los distintos ámbitos de su actividad polifacética o ya como capítulo en panoramas sobre la bibliografía española ${ }^{5}$, que pudiera servir de aceptable encuadre. Adelanto que no es mi propósito llenar ese vacío, pues el interés prevalente que me ha llevado a acercarme a La Barrera no ha sido otro que el de calibrar su enorme contribución al conocimiento de la poesía del Siglo de Oro. Pero he de confesar que conforme avanzaba en el estudio de la obra de quien creo firmemente ahora que merece ser revalorizado como uno de los mejores indagadores en el siglo XIX de esa parcela de la literatura española, fueron surgiendo iluminaciones y constataciones del mayor interés. Datos de primera mano, que en la mayoría de los casos desactivaban, cuando no refutaban de plano, la imagen unidimensional y cargada de tópicos que circula como verdad inconcusa sobre el autor del Catálogo bibliográfico y biográfico del teatro antiguo español. Como su inserción y comentario habrían descompensado mis análisis centrados en su papel como estudioso de la lírica áurea ${ }^{6}$, decidí agrupar algunos de esos datos y observaciones de forma independiente, elaborando un asedio inicial a la vida y

pionero en noticias y pesquisas de su interés al autor del Catálogo, pudo referirse en otra ocasión a "la confianza que tan gran investigador merece y lo seguro de sus afirmaciones", calificándolo de "gran erudito" ("Góngora no llamó hidiota a Lope", en Obras completas, VI, Madrid, 1982, pp. 323 y 325).

5 Lo que más se le aproxima, pese a sus exigidas limitaciones de espacio y enfoque, es el correspondiente artículo de J. Delgado Casado en Un siglo de bibliografía en España. Los concursos bibliográficos de Biblioteca Nacional (1857-1953), I, Madrid, 2001, pp. 231-239. Extremadamente pobres e incompletas son las entradas sobre La Barrera que traen R. Roldán, Diccionario biográfico y bibliográfico de autores formacéuticos españoles, I, Madrid, 1958, pp. 294-296, y A. Ruíz Cabriada, Biobibliografía del Cuerpo Facultativo de Archiveros, Bibliotecarios y Arqueólogos, Madrid, 1958, pp. 138139.

6 Una acota el más amplio proyecto de la antología y estudio que sobre la lírica áurea proyectó -y en pequeña parte culminó- el estudioso decimonónico. Está próxima a aparecer en las Actas del congreso de Ferrara (I Canzonieri di Lucrezia Borgia), con el título "Para un capítulo de la historia recepcional de la poesía del Siglo de Oro: el inédito Cancionero de poetas varios españoles de los siglos XVI y XVII de Cayetano Alberto de La Barrera". Otra, actualmente en proceso de elaboración, intenta aquilatar la importante presencia de la poesía del Siglo de Oro en el Catálogo o las contribuciones dispersas en sus estudios y notas biobibliográficas de materia cervantina y en la biografía de Lope de Vega. Analizará, además, con la minuciosidad que se merece, la edición de Rioja, seguramente la más rigurosa y documentada de las que se realizaron a lo largo del siglo XIX de un poeta de los siglos XVI y XVII. 
labores de investigación de La Barrera. Mera roturación de un terreno que exigirá mayores atenciones futuras, pero que puede servir ahora $-y$ no otra ha de ser su función ancilar- como marco presentador suficientemente fundamentado de mis propias indagaciones monográficas. Quizá, de paso, empiece a dibujarse el nuevo perfil de un estudioso vocacional que rindió su tranquilidad y hasta su bienestar al riesgo y ventura de la biobibliografía literaria del Siglo de Oro.

\section{Vida por oficio: la vocación trágica de un bibliógrafo}

Poseemos detallados y seguros datos sobre La Barrera hasta el año 1832 gracias a las páginas iniciales de un conato de autobiografía que el erudito pergeñó en los últimos meses de su vida7. Por ese fragmento de memoria personal sabemos que nació en Madrid el 7 de agosto de 1815, siendo sus padres, Antonio de La Barrera y Canales y María de la Concepción Leirado y Ortega, "ambos naturales de esta corte". En la familia paterna, de origen soriano, había sido norma y costumbre durante varias generaciones la carrera militar, quebrándose tan añeja tradición con su progenitor. Éste, tras licenciarse en farmacia, había regentado primero una botica en la calle de la Luna y luego otra en la Puerta de Moros. Inició el futuro bibliógrafo su formación en el Colegio Imperial de la Compañía de Jesús, con estudios de latinidad y un curso de lógica y de matemáticas. Y aunque su vocación inicial, según recuerda, lo inclinaba a la jurisprudencia, obtuvo el grado de bachiller en filosofía en el Colegio de San Carlos, empezando a cursar en 1831 la carrera de medicina. Aquí se interrumpen los apuntes autobiográficos sirviendo de muy poca ayuda la semblanza de J. E. Hartzenbusch en que se inserta, pues no entabló su autor amistad con La Barrera hasta muchos años después, cuando éste era "licenciado ya en Farmacia y con botica propia en Madrid". Pero justamente entra en juego para las fechas casi inmediatas la interesantísima correspondencia con don Francisco de Borja Pavón, que constituye la guía más precisa para conocer con abundantes detalles muchos entresijos de la vida y del sentir de La Barrera ${ }^{8}$.

${ }^{7}$ Las reprodujo J. E. Hartzenbusch haciéndolas preceder de la siguiente explicación: "A instancias de un amigo suyo, había principiado a extender unas notas autobiográficas, de las cuales se han hallado entre sus papeles tres plieguecillos, escritos de su hermosa letra, como si fuesen ya copia de trabajo concluido; el borrador empero, ni de la parte escrita ni de lo que falta, no ha parecido. Transcribo, pues, aquí lo que tenemos de dichas noticias, respetando hasta la ortografía con que aparecen" (op. cit., pp. 10-13).

8 Se encuentra reunida por orden cronológico, abarcando los años comprendidos entre 1836 y 1868, en el Ms. 19599 de la B. N. de Madrid: Cartas de varios literatos a D. Francisco de Borja y Pavón, cronista que fue de Córdoba, y minutas o copia autógrafas de muchas de las dirigidas por él a los mismos. Aunque en el volumen se acogen cartas de José Amador de los Ríos, Pascual Gayangos, Aureliano Fernández Guerra, Eugenio Ochoa, Adolfo de Castro o Juan Valera, entre otros, el destinatario 
Riesgo y ventura de un gran bibliógrafo...

Habiendo terminado la carrera de farmacéutico en 1837, escribe el 19 de junio de 1841 a quien pronto sería su amigo y más fiel confidente: "Aún cuando, como Vd. sabe, me hallo ejercitando la profesión en compañía de mi padre, mi salud delicada exige, y la conveniencia de hacer algún adelanto aconseja, mi establecimiento en un partido regular cuya situación sea, si es posible en un clima templado". Informado positivamente por su corresponsal de que podía regentar una farmacia "ventajosamente" en Martos, "población rica y de numeroso vecindario" (carta de 6 de agosto de 1841), vivirá ejerciendo su profesión en dicho pueblo cordobés durante dos años. Pese a la mejoría de salud y a la despreocupación placentera respecto a compromisos y pasiones políticas que le supuso el retiro a Martos 9 , quiso retornar muy pronto a la capital. Desde Pozuelo del Rey escribe el 3 de noviembre de 1843: "Hemos hecho la segunda locura dejando a Martos con el ansia de volver a nuestro Madrid, para después vernos precisados a rematar en una aldea. Aquí a cinco mil pies sobre el nivel del mar podemos apreciar ya lo que es el clima que hemos abandonado. En cuanto a las utilidades no me parece que saldremos más gananciosos".

Entre esas "utilidades", y por encima ya de la marcha de su economía, figuraba en lugar preferente la insaciable voracidad del bibliógrafo en ciernes. Era la verdadera pasión de La Barrera, nacida muy pronto y crecida con exclusividad vertiginosa, constituyéndose junto a la bibliofilia en lo que Hartzenbusch llamó "sus aficiones continuas". Desde ella se explica la reacción melancólica ante la imposibilidad de poder responder de inmediato a las noticias que le solicitara Borja Pavón: "Serán mi primer cuidado si alguna vez, que no lo espero, logro volver a pisar las bibliotecas de Madrid". Pero muy pronto, a finales de 1844, ya estaba definitivamente afincado en la capital estableciéndose "en la calle de San Bartolomé frente a la Plaza de Bilbao". "Prosperó esta oficina habiéndola regido por mí cuatro años, desde 1852 en que mis padres fallecieron", recapitula en carta de 20 de mayo de 1859. Sobre ese

sólo escribió precediendo a la correspondencia con La Barrera: "Digna de conservarse con especial cuidado y estima". Según noticia imprecisa del citado Diccionario de R. Roldán algunas de estas cartas están publicadas, aunque no he logrado corroborar cuándo, dónde, ni por quién. En cualquier caso nunca han sido tenidas en cuenta hasta ahora. En mis citas normalizo los textos, tanto de las cartas como de otros autógrafos de La Barrera, evitando el enfadoso escollo que representa su peculiar sistema ortográfico.

${ }^{9}$ En la carta de 21 de diciembre de 1843 escribe: "Tengo que rectificar esa otra idea que Vd ha concebido: estoy tan distante de haberla formado desfavorablemente de Andalucía, siquiera no sea el del bel Santo-reino su mejor territorio, que, por el contrario, he observado y admirado en él lo suficiente para figurarme lo que será la parte más bella y principal de ese suelo privilegiado". Y tras lamentarse de la pobreza del suelo castellano cuenta a su amigo cómo había traído "una colección de espigas de Martos, que han sido objeto de admiración y de sorpresa aun para personas ilustradas que se dedican al cultivo de estos ingratos campos con la más esmerada inteligencia". 
período da una pincelada expresiva el elogio póstumo hecho por el autor de Los amantes de Teruel: "Cuando entablamos amistad en esta casa, con el motivo, muy frecuente en ella, de proporcionar unos libros, La Barrera [...] con botica propia en Madrid, soltero y con algunos bienes, empleaba parte de ellos crecida en compra de libros y de manuscritos curiosos". Para zafarse de cualquier trabajo ajeno a sus absorbentes investigaciones enajenó la farmacia familiar a finales de 1856, "y subsisto -confiesa a A. de Latour en carta de 1861- con el producto de una finca que poseo en esta capital, adquirida por herencia en el año 1852"10.

Los años más fecundos del bibliógrafo tuvieron un abrupto corte final con el cataclismo de su economía. Hartzenbusch lo rememora con expresivo laconismo: "Para satisfacer La Barrera su pasión de trabajar en el retiro de su morada, sin buscar auxilios ajenos, había vendido su botica y una casa pequeña que poseía; impuso el producto de ambas enajenaciones en una de esas sociedades de grandes esperanzas que nunca se cumplen, $\mathrm{y}$, como es de suponer, lo perdió casi todo". Del hecho, sobrevenido cuando por su cambio de estado más precisaba de una estabilidad económica, dio pormenorizada cuenta el erudito en sus cartas. Como encierran alguna importante discrepancia en el orden de los acontecimientos transcribiré lo que dicen las dirigidas a Latour y Borja Pavón. En la primera, de 10 de septiembre de 1867, escribe: "Aquel filósofo retraído y encastillado en su inexpugnable ciudadela, pintado por V. E. en dos preciosas obras de su pluma, ha venido por fin a los 51 años de su edad a capitular con la sociedad, doblando su cerviz al santo yugo del matrimonio. El 12 de enero de este año le contraje en la parroquia de San Justo y Pastor de esta corte con doña María de Loreto Hernández Cornejo, natural de la misma, encontrando en este enlace toda la felicidad moral que puede esperar el hombre de una consorte amante y virtuosa [...]. A poco de realizado mi enlace, y cuando las nuevas obligaciones me exigían más seguros y abundantes medios de subsistencia, he tenido la desgracia de perder en una sociedad de crédito la mitad de mi pequeño capital". En la segunda, de 21 de junio de 1868, se adensan con cierto desorden las evocaciones: "Los sucesos míos desde que nuestra correspondencia quedó interrumpida han sido tales que no pueden referirse brevemente: su prolija relación acabaría con la paciencia de $\mathrm{Vd}$ y de cualquier oyente [...] Perdí en una sociedad de crédito la mitad de pequeño capital con que vivía independiente [...] que luego estuve gravísimamente enfermo [...], que después, harto de vida frailesca y solitaria, me casé (el 12 de enero de 1867) logrando una esposa modelo de virtud y de cariño; que soy padre de una hermosísima niña".

10 Las cartas a A. de Latour fueron publicadas por A. Morel Fatio, "Cayetano Alberto de La Barrera", en Bulletin Hispanique, XIX (1917), pp. 116-122. 
Riesgo y ventura de un gran bibliógrafo...

No resultó nada fácil para La Barrera encontrar una salida a tan exasperante como inesperada situación. El relato oficial del director de la Biblioteca Nacional se limita a decir que "la calificación brillante de su Catálogo le daba derecho a plaza en biblioteca pública, y hubo de refugiarse en la nuestra, para reparar de algún modo la pérdida de sus intereses". Pero el camino resultó de hecho bastante más tortuoso. Como explicaba La Barrera a Latour en la continuación de la carta antecitada: "Reducido así al triste extremo de abandonar las letras, vender mis libros y volver al ejercicio de mi profesión, me decidí, fundando grandes esperanzas en la Real Orden de 27 de diciembre de 1860, por la cual el Gobierno me concedió opción a plazas de gracia en el cuerpo de Archiveros-Bibliotecarios, y siguiendo el consejo de varios amigos, a solicitar una de esas plazas [...] Muchos y de muy distinguida posición social y literaria se han interesado por mí, pero hasta el día sin favorable resultado". Fueron la decidida vocación del estudioso, mantenida contra viento y marea, y su prestigio, avalado por un amplio conjunto de personalidades, que reclamadas por él presionaron con sus recomendaciones al ministro de Fomento ${ }^{11}$, los que consiguieron salvarlo. Cambiando incluso una resolución inicialmente negativa "por razón de que las economías introducidas en el presupuesto del ramo hacían necesaria la supresión de plazas". A Borja Pavón le recordará la "activa diligencia" en el asunto de Asenjo Barbieri y lo mucho que debió su final nombramiento "a la bondad de S. A. la señora Duquesa de Sessa". En la última de sus cartas enderezadas a A. de Latour, de 5 de noviembre de 1867, le cuenta el afortunado azar que le permitió no tener que abandonar Madrid: "El 28 quedé nombrado oficial del Cuerpo, con destino a la Biblioteca de Zaragoza [...] Habiendo comenzado ayer la presente, hube de interrumpir mi tarea. Entretanto, uno de los oficiales de la Biblioteca Nacional me ha hecho proposición de permuta, que yo he aceptado con el empressement que V. E. puede figurarse".

Los últimos años de su vida La Barrera ejerció en cierto modo una profesión con la que había soñado, aunque en un rango muy inferior al que pedían sus méritos y conocimientos ${ }^{12}$. En la España donde triunfaban y

\footnotetext{
11 La carta de A. de Latour se cierra pidiéndole que haga lo posible por "favorecer mi pretensión". Otra más escueta y directa, dirigida a M. Cañete en carta de 26 de junio de 1867, concluye igualmente: "La influencia de Vd pudiera favorecer muy señaladamente esta pretensión mía" (Correspondencias literarias del siglo XIX, Ed. de J. M. Cossío, Santander, 1936, p. 155).

12 Antes del desastre financiero y del matrimonio, la pasión bibliográfica de La Barrera se manifestó de forma ideal y absoluta en la "disposición testamentaria" hecha desde 1852 y recordada en carta de 1865: "Tengo legados mis libros y el remanente de mis bienes a la Biblioteca Nacional". La final adquisición por parte del Estado y con destino a dicho establecimiento de la mayor parte de los libros de La Barrera tras su desastrada muerte, proyecta la sombra de un cruel sarcasmo sobre tan altruista deseo.
} 
seguirían cosechando laureles y prebendas eruditos tan mediocres como A. de Castro o C. Rosell, el más grande de los bibliógrafos en activo vino a ocupar, tras ímprobos esfuerzos contra una administración tan laxa en ocasiones menos justificadas, el modestísimo puesto de oficial tercero en la sección de manuscritos de la Biblioteca Nacional. Encargado de la engorrosa labor de formar un índice completo por materias, dedicaría a empeño tan infructuoso como inalcanzable buena parte de sus energías. Según confesaba a Borja Pavón, sus "tareas propias" se habían reducido al "perfeccionamiento", mediante la interminable labor de "rectificar y enmendar", de sus obras mayores (la Nueva biografía de Lope de Vega y el Catálogo): "Para ellas no hace falta ya el tiempo, pues claro está que no he de robárselo a las ocupaciones de mi destino; y por otra parte, los cuidados y relaciones de mi nueva vida me cercenan la mitad del que en mi casa pudiera destinar a estos trabajos". Poco tiempo le daría además la vida, pues falleció el 30 de octubre de 1872 en las lamentables condiciones que conmovieron incluso al impasible Hartzenbusch: "Ha muerto pobre y con la familia en la infancia y se ha solicitado al Congreso una corta pensión para la viuda y los pedazos de sus entrañas [...] Esperemos que allá donde se hacen las leyes entre el recio choque de las violentas pasiones, se oiga la voz de una infeliz que ha dicho en un memorial: Ha muerto mi esposo dejándome con tres hijas, la mayor de cuatro años, la menor de pecho, que no vive en el mío"13.

\section{Elementos para una etopeya: La Barrera frente a su entorno}

Aunque la recién esbozada biografía externa deja entrever algunos rasgos determinantes de su carácter y formación, está lejos de conformar un marco explicativo de la gigantesca labor planificada y en parte culminada por La Barrera. Es más, algunos episodios de esa biografía, como su ruina económica, junto a actitudes más o menos anecdóticas y pintorescas han contribuido no poco a difundir una imagen inexacta -hasta bordear en algún caso lo grotesco- de él como erudito atrabiliario y caprichoso ${ }^{14}$. La verdad es muy otra, y como en el caso de Gallardo acaso convenga iniciar el desvelamiento -y debelamiento- de otra "infamia" convertida en tópico. Bajo la inmensa mole de sus obras de erudición y el vasto aliento de su programa de trabajo hay bastante más que una compulsiva manía bibliofílica o el refugio de

\footnotetext{
13 El 5 de diciembre de ese año el diario madrileño La Discusión daba la noticia acerca de una "proposición de ley para que se conceda una pensión a la pobre viuda e hijas menores del célebre biógrafo y bibliógrafo don Cayetano Alberto de La Barrera" (J. Fernández Sánchez, Historia de la bibliografía en España, Madrid, 1994, p. 210).

14 Así ocurre en el esbozo a vuelapluma de P. Sáinz Rodríguez, donde se da por toda definición que "era un hombre muy apasionado pero muy culto y ceremonioso" precediendo a la acogida de circunstancias intrascendentes sobre el último aspecto (p. 213).
} 
Riesgo y ventura de un gran bibliógrafo...

un misántropo. Late la idea coherente del destino final en una historia literaria de nueva planta, a que habían de servir la preparación de instrumentos biobibliográficos lo más exhaustivos y precisos posibles. Y consecuentemente, La Barrera supo asumir el voluntario renunciamiento de todo cuanto no condujese a la perfección de unas obras que sentarían los cimientos sobre los que otras generaciones debían levantar el monumento debido a la literatura española del Siglo de Oro. Perfección que pese a la laboriosidad infatigable por él desplegada casi nunca llegaron a alcanzar a sus ojos, empeñado como estaba siempre en completar, precisar y cuando consideró necesario rectificar, los ingentes materiales que había conseguido reunir. Si causa asombro lo allegado por él, más de admirar es contemplarlo como producto del compromiso sin fisuras con un oficio que se sabía tránsito y peldaño para más elevados quehaceres historiográficos.

La simple lectura de las cartas de La Barrera faculta para esbozar una contraimagen matizada de los móviles que le llevaron a empeñar todos sus afanes en la biobibliografía literaria. Sin llegar casi nunca a la confesión íntima, antes bien veladas incluso en los momentos de más desahogo personal por un respeto pudoroso y una exquisita cortesía ${ }^{15}$, esas cartas contienen suficientes precisiones acerca de su conducta, sus muchas renuncias y sus legítimas ambiciones. A retazos, permiten recomponer una etopeya bastante fiable del hombre y del erudito. En cuanto a la primera vertiente resultan llamativas sus frecuentes autocríticas, ya sobre los "geniales achaques de quisicosillas y egoísmo", ya sobre sus "trazas, modales y fama, objeto de burla y merecida sátira". También sus reflexiones sobre la edad que le atribuyen los demás. En carta a A. de Latour le aclara: "Mis años no llegan aun a la media centuria: acabo de cumplir los 46 [...] Generalmente me dicen que represento menos edad de lo que en realidad cuento: sin duda los informantes de $\mathrm{V}$. E. tienen diverso modo de ver, y si han juzgado por la madurez y seso que tal vez me atribuyen les debo de estar agradecido". En otra a Borja Pavón la confidencia da lugar a una expansión significativa tanto por lo que deja entrever de la vida privada de La Barrera como por la contundente crítica de su propia máscara obligada por la hipocresía social. Acaba de cumplir 51 años, "aunque nadie me da de los que ignoran mi edad arriba de $44[\ldots]$ ¿No es cierto que en este momento mismo se inclina a juzgar debido a mi continente moralidad esta resistencia de mi físico a las señales que son preludio de la vejez? Pues amigo mío, si Vd lo piensa así

15 Es significativo, ante un prolongado silencio de su corresponsal, el comienzo de la carta de 12 de agosto de 1866: "Más que enojado estaba yo pesaroso de haber quizás herido con aquella mi [carta] certificada y reservada, alguna susceptibilidad de $\mathrm{Vd}$, o de haberle tal vez fastidiado con inoportunas confianzas sobre cuestiones personales mías que naturalmente debían de interesarle poco, por más que tuviesen tal cual enlace con sucesos literarios". 
completamente se equivoca. Todo aquello no era sino reserva y ficción hipócrita, forzada consecuencia de una educación errónea, la que generalmente se da en esta sociedad detestable, contrariando las leyes y los deberes naturales. A pesar de todas las contrariedades, la Deesse de Paphos ha estado bien satisfecha de mi constante aunque privado culto desde que cumplí los dos septenarios". Otra preocupación constante en sus misivas es la referida a la salud. La Barrera la tuvo siempre "delicada"16, padeciendo dolencias crónicas que le hicieron ser especialmente sensible y ácido frente a los fáciles consejos de colegas y conocidos del mundo de las letras cuando lo consideraban un hipocondríaco. Valga de muestra este pasaje de la carta de 5 de septiembre de 1861: "Fui atacado de mi antiguo catarro bronquial con más intensidad que nunca, por haberse complicado con el epidémico entonces reinante. Estuve en cama veinte días; la espectoración presentó algunas estrías sanguinolientas y hubo otros síntomas de alguna gravedad [...] Lo que me consoló sobre todo fue el saber que según la opinión de uno que otro grande ingenio yo solamente adolezco de aprensión. Los poetas lo saben todo: son grandes filósofos y también médicos y excelentes didascálicos.".

Particular interés revisten las opiniones del bibliógrafo sobre la política nacional. Su temprano posicionamiento y el todavía juvenil entusiasmo llenan la primera de las cartas enderezadas a Borja Pavón. Comenta así a su corresponsal los previsibles resultados de las elecciones cordobesas: "Verdaderamente nada extrañaré que esa levítica población haya dado su voto a los escogidos, no del señor, que éstos andan en los cielos, sino del actual gabinete. Otro tanto ha hecho la imperial ciudad nuestra vecina. Pero Córdoba no es más que un pueblo y un ánima sola ni canta ni llora". Luego contesta de esta forma a la pregunta sobre su "sentir en vista de los últimos sucesos de la guerra": "Lo haré francamente, declarándole que los tengo por forzosa consecuencia de la retirada del ministerio Mendizábal y de los altos planes [...] Cada mes de devastación y de ruina retrasa un año la consolidación del edificio constitucional y consiguientemente la regeneración de esta patria infeliz". Y termina, tras otros comentarios sobre el asunto, pidiendo expresivas disculpas a su amigo: "Yo soy extremado en todas mis cosas y $\mathrm{Vd}$ me ha dado pie para hablar de las que más ocupan mi atención, no en verdad por político-manía, sino por amor al país donde vi la luz primera". Pronto se apaciguaron sus fervores, fobias y afinidades, que nunca llegaron a la participación activa en política. Ya en carta de 21 de diciembre de 1843 le indica a su corresponsal que ha tocado un punto "sobre el cual hace tiempo que habrá notado mi absoluto silencio: hablo

16 Contestando a Borja Pavón entonces enfermo, le dice el 20 de mayo de 1859: "Molesta en extremo debe ser esa dolencia, pero $\mathrm{Vd}$ a lo menos sabe a qué atenerse en ese punto, y yo le envidio en cierta manera porque soy un tratado completo de patología". 
Riesgo y ventura de un gran bibliógrafo...

de la política. Amigo, las desgracias propias me han hecho olvidar las de la patria, prestándome tan grande beneficio como haberme curado de esa manía. Por lo menos he gustado un nuevo placer: el de pasar dos años sin saber jota de achaques de ministerios ni de elecciones, de colores, matices, ni pintura de ninguna especie". Retraído pero no indiferente, y marcando siempre una insalvable distancia con las corruptelas del poder y con las servidumbres a que no quisieron o no supieron resistirse otros eruditos de su entorno. Es muy significativa al respecto la denuncia que hace a Borja Pavón, en carta reservada de 26 de enero de 1865, del intento por parte de Aureliano Fernández Guerra de afiliarlo al partido de Cándido Nocedal: "A mí se me juzgaba no diré necesario pero sí muy útil para ciertos proyectos [...] Creyóse también que en este clásico país de la pesca no había de ser imposible el pescarme [...] Yo navegaba viento en popa. Soplábame suavísimamente una graciosísisma opción a plaza de gracia [...] Excusado me parece el indicarle, dado que le son conocidas mis especiales y personales circunstancias, cómo recibiría yo la parte del fresquísimo oficio en que se me mostraba el camino de las pretensiones y en lontananza el risueño porvenir de llegar a verme útil operario de la viña [...] La gracia no era, sin embargo, gratis data. Aparte de aquello que no suena y se oye y ve venir: del intento de catequizarme para el bando de Nocedal y compañía, se me hicieron en el tono dominante propio de la persona que arriba dejo nombrada insinuaciones literarias a que no podía prestarme en manera alguna". Con insobornable contundencia, La Barrera define así sus relaciones con el editor de Quevedo: "Han continuado por largo tiempo exclusiva y puramente literarias, pues en lo que se refiere a otros puntos de mayor importancia para la triste humanidad entre sus opiniones y las mías hay un muro de bronce y por el foso corre sangre".

Tomando pie en los elogios de Borja Pavón a sus cualidades y entrega ilimitada al trabajo de investigación, trazó La Barrera un escueto pero clarificador apunte acerca de la labor biobibliográfica en la carta de 20 de mayo de 1859: "Vd, amigo, me sonroja con sus encomios: más severa y menos amistosa crítica deseara yo para mí. No quiero sin embargo afectar modestia, y así convengo desde luego en la calificación apreciativa que $\mathrm{Vd}$ hace de mis talentos e inclinaciones. Del gusto rebajaremos un poco, y añadiremos un apasionado instinto de método y clasificación, que sin duda debe ser hijo legítimo de la colectividad, que es mi facultad dominante. Procuro escribir con alguna corrección: respecto del estilo ni yo acertaría jamás a engalanarle ni mis tareas se prestan a semejantes galas y perifollos ${ }^{17}$. Minuciosidad prolija,

17 Habría que matizar que salvo cuando el fragor de las lides polémicas caldeaba su pluma. Entonces La Barrera se permitía disponer de una variadísima gama de registros para su contundente argumentación y eficaz dialéctica. Con momentos antológicos que no desdicen de la 
acompasada, cavilosa y escrupulizante; citas y citotes, fechas y más fechas, notas y renotas. ¡Vea usted qué lindo aliño de estilo el de mis gacetas biobibliográficas! Indigesto llaman los inteligentes a este modo de escribir. Pero yo en tales materias digiero con asombrosa facilidad". La significativa sindéresis entre el estilo apropiado para la creación literaria y el que exige una tarea auxiliar de la historia literaria no era moneda común en esos años. Los eruditos o manejaban ambos registros (desde Mesoneros Romanos a Hartzenbusch) o pretendían dotar a los productos de su pluma de atildamientos y estrategias discursivas más propias de la oratoria o de la novela (buen ejemplo de una y de otra en Aureliano y Luis Fernández Guerra) ${ }^{18}$. Por eso mismo resalta la contundencia extrema con que La Barrera explicitaba poco después, en carta de 28 de Junio de 1859: "Quisiera que por lo respectivo a escrúpulos literarios (contrayéndome a la bio-bibliografía) figurara mi nombre, allá entre las memorias eruditas que de nuestro siglo se conserven, algo distante del capítulo de los autores ficúlneos [...] No bajo otro concepto me llamé yo escrupulizante. En este punto llego hasta el extremo de opinar que debía de ser vedada en las obras de inventiva toda alteración, por pequeña que fuese, de la historia política

alacridad y vis cómica propias de su admirado B. J. Gallardo. Sirva de ejemplo representativo la pintura del Buscapié como un nuevo retablo de maravillas: "Concluida la celestial sinfonía del prólogo hiere los oídos el agudo silbo del tramoyista y descríbese chafarrinada de almagro, sombra de viejo y ocre la decoración. Maese Adolfo, entre bambalinas, menea los monigotes y con habilidad ventrilocuaz, ya finge voces, ya remeda relinchos. Los literatos pandillistas de primera fila prestan favor al titiritero con su circunspecto y diplomático silencio; ríe y aplaude la manada de ingenios pollos, eruditos del último figurín" (El Cachetero del Buscapié, Santander, 1916, p. 60).

18 Respecto a A. Fernández Guerra resulta significativo leer entre líneas la extensísima nota sobre Juan Sánchez Burguillos incluida en la biografía de Lope. La Barrera cuenta cómo facilitó al autor de la "exquisita" edición de Quevedo la correspondiente biobibliografía de su Cancionero de poetas varios españoles de los siglos XVI y XVII: "En efecto -prosigue- reunió dicho señor, a las noticias que sobre tan curioso punto había por sí propio investigado y descubierto, las comprendidas en mi artículo que le eran nuevas; y conservando el plan bajo el cual yo le redacté, y algunos de sus períodos (honor bien poco merecido de mi tosca pluma) escribió una erudita Nota [...] o por mejor decir, discurso "(Nueva biografía...cit., I, pp. 319-328). Sobre la monografía acerca de Juan Ruíz de Alarcón publicada por L. Fernández Guerra un año antes de la muerte de La Barrera, y en la que también se aprovechaban las "revelaciones" desentrañadas por éste en su por entonces silenciada biografía del Fénix, no se conoce juicio alguno del bibliógrafo. Pero de seguro no habría suscrito el ditirámbico elogio de Menéndez Pelayo centrado en cómo se realzaba la investigación "con toques de pincel valentísimo" sumando a su "diligencia de erudito" la "fantasía de poeta" (loc. cit., II, pp. 177). Siendo en sí misma la de Lope una "novelesca vida", y contando La Barrera con "inestimables materiales autobiográficos" y "considerable número de interesantísimos datos" extraídos con un "prolijo examen de las obras todas del insigne escritor" quiso huir de cualquier forma de invención o efectismo retórico. Su blasón diferenciador era bien explícito: "Los lectores que sigan aquella detestable aunque no desvalida máxima del celebrado pintor y poeta Pablo de Céspedes: Los retratos no se han de parecer; lo que importa es hacer una valiente cabeza, pueden desde luego cerrar el libro y excusarse la molestia y el disgusto que habría de darles este mi trabajo biográfico" (loc. cit., I, pp. 10-11). 
Riesgo y ventura de un gran bibliógrafo...

o literaria, toda suposición de pormenores biográficos. $\mathrm{Vd}$ es tolerante $\mathrm{y}$ escuchará benévolo esta heterodoxa y excéntrica opinión". Quien así opinaba se había restringido voluntaria y definitivamente al mundo de los libros españoles antiguos y, salvando muy pequeñas parcelas de lo contemporáneo, había renunciado al menor conocimiento de la literatura viva. Por ello se explica, además de por su independencia frente al diseño de una clara operación de dirigismo cultural, su rechazo a la propuesta de escribir un Catálogo biobibliográfico del teatro moderno español: "Bajo ningún concepto podía yo emplearme en tarea semejante. No me han ocupado nunca seriamente acerca de los modernos escritores de todo género otros estudios bibliográficos que los relativos a Gallardo [...] Los modernos repertorios me son casi desconocidos: no leo comedias y hace 23 años que no piso los teatros" (carta de 26 de enero de 1865).

No era La Barrera un estudioso pagado de sí mismo. En realidad, sólo en contados momentos se dejó arrastrar por la euforia que exhibe la carta de 6 de enero de 1860: "Un motivillo de vanidad (¡mal grado!) me pone la pluma en la mano. He sido agraciado con el primer premio en el certamen de la Biblioteca Nacional por mi Catálogo biográfico del teatro antiguo español cuya impresión está ya decretada [...] Aunque según cierto escritor moderno esta clase de trabajos no dan gloria alguna, yo me observo un tantico envanecido y debo de estarlo con los testimonios de unánime aprecio que de los jueces y otras personas ha recibido mi obra". No se preocupaba por seguir la estela exitosa de algunas de sus publicaciones, ni siquiera del Catálogo, "divulgado -según indicaría Hartzenbusch- por España y fuera, y aún de los límites de Europa; reconocido por señaladísimo en su clase"19. Aunque agradece a su amigo el "favorable juicio" sobre dicha obra le comunica el 5 de septiembre de 1861: "De los 150 ejemplares que se me dieron regalé (porque así se me previno) a los principales periódicos de Madrid, pero no he cuidado de saber si han escrito algo en crítica del libro. Sólo he visto el artículo que en el Museo Universal publicó el Sr. Manuel Murguía (a quien ni aun de vista conozco) elogiando la obra". Y en la carta de 26 de enero de 1865 remacha: "Por lo tocante a favorables juicios de mi escaso valor literario puedo asegurar a Vd que mi indiferencia es grande: así de los que se hicieron de mi Catálogo a esta fecha solamente he leído el que escribió D. Manuel Murguía en el Museo Universal". Nada iba a afectar, por tanto, a la vocación de retiro para la entrega a los solaces eruditos que reclamaban

\footnotetext{
${ }^{19}$ En el mismo sentido, A. Durán recordará que el Catálogo había merecido "la más grata acogida por parte del público, de las personas doctas y de los amantes de nuestras glorias literarias. Su autor, D. Cayetano Alberto de La Barrera, ha hecho a su patria un verdadero servicio y ha sabido labrarse una envidiable reputación" (Memorias leídas en la Biblioteca Nacional en las sesiones públicas de los años 1860, 1861 y 1862, Madrid, 1874, pp. 20-21).
} 
incesantemente todo su tiempo y esfuerzo. De esta forma concluye la carta antecitada de 1861: "Vd figurará tal vez, mi amigo, que yo, a consecuencia de la publicación y buen acogimiento de esa parte de mis elucubraciones biobibliográficas y del honrarme con sus saludos y felicitaciones algunos señores de excelencia, habré cambiado de vida y de otras cosas y salido de mi huronera. Nada menos que eso. Retraída está la infanta / mucho más que no solía. Cada vez más separado de todo trato y comunicación y le aseguro que este método higiénico, a lo Juan Portal, me prueba divinamente".

Los únicos destellos de envanecimiento que se sorprenden en el epistolario de La Barrera constituyen el envés de unas cualidades tan evidentes que difícilmente podría haber esquivado tener que referirse a ellas: la laboriosidad y la generosidad. El gran bibliógrafo conocía mejor que nadie la novedad y la entidad de muchos de sus aportes, por lo que no pasa de venial prurito su insistencia (que casi como muletilla formularia repite en sus obras) en declarar los materiales "numerosos [...] logrados por mí propio" (carta de 5 de septiembre de 1861), las biografías y bibliografías "ricas de noticias debidas a mi diligencia" (carta de 12 de agosto de 1866), los "datos y documentos debidos a mi diligencia" (carta de 21 de junio de 1868). Por otra parte resulta proverbial el desprendimiento con que facilitaba "noticias, libros y papeles", allanando investigaciones ajenas a costa incluso de las propias. Era para él un motivo de legítimo orgullo, que se manifestaba de esta forma en la carta de 20 de mayo de 1859: "Mi buen deseo de ilustrar nuestra descuidada historia literaria y la generosidad con que yo franqueo cuanto puedo hallar de útil y curioso para este objeto me han granjeado el aprecio y la benévola amistad de algunos insignes escritores. Los Sres. D. Aureliano y D. Luis Fernández Guerra, D. Juan E. Hartzenbusch, D. Manuel Cañete, D. José Fernández Espino y algún otro me han honrado públicamente de una manera que estoy bien distante de merecer".

El norte de su infatigable quehacer no fue otro que rendir tributo a la verdad sin aceptar mixtificaciones ni componendas. "No puedo escribir biografías de personas que viven porque acostumbro a tratar verdad", asegura en carta de 26 de enero de 1865. Una verdad siempre problemática en aquella España tan pagada de falsos relumbres partidistas como rendida a la más hipócrita de las gazmoñerías, según comprobaría el bibliógrafo en dos episodios no poco ejemplares: la controversia del Buscapié y la censura de su biografía de Lope de Vega que había elaborado a la luz de las cartas del Fénix al duque de Sessa entonces recién aparecidas.

La superchería del erudito gaditano, el pastiche en el que "ha ocultado, ha supuesto, ha tergiversado, ha fingido, ha compaginado a su gusto", no venía a ser para La Barrera sino la audacia consentida de alguien "loco de vanidad y ciego de codicia, extremadamente fiado en la ligereza y superficialidad de la 
Riesgo y ventura de un gran bibliógrafo...

época en que vivimos"20. El ácido ataque al Buscapié improvisado con maestría y soltura por B. J. Gallardo no se enderezaba, por ello, sólo al falsario: "tocábales su buena parte a cientos y cientos de la dominante pandilla político-literaria que entonces apadrinaba ciegamente a don Adolfo de Castro". La Barrera tomó la antorcha de su maestro en lides bibliográficas redactando entre 1849 y 1866 el demoledor y eruditísimo El Cachetero del Buscapié, cuyo subtítulo reza expresivamente: Resumen de las pruebas de hecho y de las razones críticas que evidencian la falsedad del "Buscapié" de Don Adolfo de Castro y la del otro tal que se mintió en el pasado siglo. Sabedor de que con ello se enfrentaba también a la "ciega animosidad política, en ningún partido más ciega, intolerante y vengativa que en el híbrido inmoral y monstruoso de la unión odonelina, a que pertenecen los señores Estébanez, Cánovas y Barrantes y acaso también pertenezca al converso don Adolfo". Y adivinador de lo que finalmente sucedería con su libro y ya barruntaba en carta de 22 de agosto de 1866: "He rehecho con grandes mejoras y aumentos mi Cachetero del Buscapié que tampoco puede imprimirse porque dice la verdad". Sólo en 1916 y tras no pocos avatares ${ }^{21}$, el manuscrito vería la luz, cuando la sistemática denuncia de La Barrera era poco más que un jugoso excipiente que venía a golpear sobre las ruinas de lo que hacía décadas no contaba sino como curiosidad extravagante y juguete caprichoso de la erudición decimonónica.

No fue similar el destino de otra obra consagrada a más alto empeño histórico-crítico, aunque en este caso el ejercicio directo de la censura dictado por colegas y amigos tuviera un efecto aun más amargo y desalentador sobre La Barrera. Como los complejos entresijos del asunto distan mucho de ser conocidos en su verdadero alcance y calado, considero que se hacen merecedores de una particular atención. Según recuerda el propio biógrafo del Fénix en extensa nota a su "Advertencia preliminar", fue Agustín Durán el primer estudioso moderno que gozó la ocasión de conocer y manejar una colección de volúmenes que habían pertenecido al archivo del Duque de Sessa y que contenían "cartas originales de Lope, autógrafas la mayor parte y las de

20 Ésta y las citas que siguen proceden de C. A. de La Barrera, El Cachetero del Buscapié, cit., pp. 12 y 59-60.

${ }^{21}$ El manuscrito llegó a Menéndez Pelayo como regalo de Asenjo Barbieri, aunque antes "pasó por diversas manos", según recuerda F. Rodríguez Marín (ed. cit, p. VI). La Barrera, desesperanzado de poder publicar su obra, había cedido en 1869 la puesta en limpio definitiva a su amigo y también cervantista don José María Asensio y Toledo. En vida de su autor sólo pudo ver la luz la parte más inocua y descomprometida, la que versa sobre los antecedentes de la superchería, como "Conjeturas sobre el fundamento que pudo tener la idea que dio origen a la patraña de $E l$ Buscapié", en Revista de Ciencias, Literatura y Artes, II (1856), pp. 731-741 y III (1856), pp. 5-22, 69-80, 207-220 y 261-272. Antes de 1916, L. Ríus concedió un extenso resumen a la obra de La Barrera leída en el "hermoso manuscrito", y destacándola de entre todas las confutaciones del Buscapié (Bibliografía de las obras de Miguel de Cervantes Saavedra, III, Madrid, 1904, pp. 422-424) 
mano ajena por él firmadas"22. Durán comenzó un traslado que dejó interrumpido tras haber copiado las sesenta y dos cartas iniciales y del que dependerían las primeras noticias y fragmentos publicados por A. F. Schack en $1854^{23}$. Desde la obra de éste y antes que nadie, La Barrera atisbó el excepcional valor documental de esas cartas ${ }^{24}$, reproduciendo párrafos de las mismas en un artículo de 1857 y en el Catálogo de 1860. Su avivado interés le llevó a pedir a Hartzenbusch la copia del traslado de Durán (con destino a ser empleada para el comento del Quijote en la edición de Argamasilla de Alba) "que me facilitó y yo a mi vez hice copiar". No contento con ello, consiguió que Durán "poco antes de su fallecimiento" (ocurrido en 1862) le prestase la ya mítica y anhelada copia parcial de los originales del Fénix, que con su escrupulosa pulcritud La Barrera se entretendría en "trasladar, ordenar y anotar". Era, por consiguiente, el único estudioso verdaderamente preparado para calibrar la importancia de la reaparición en abril de 1863, con motivo de "ciertas investigaciones históricoliterarias" que llevaba a cabo T. Muñoz y Romero en el archivo de los condes de Altamira, de "tres tomos en folio de cartas originales, y en su mayor parte autógrafas, de Lope de Vega Carpio, que se guardaban reservados en aquel archivo y son restos de una colección (según he oído asegurar) que constaba de ocho a nueve volúmenes"25. Puestos a disposición esos volúmenes de la Biblioteca Nacional "para que en el mismo archivo [...] se sacase de ellos un completo y genuino traslado", la perfecta labor culminada por I. Rosell posibilitó que muy pronto La Barrera disfrutara de una copia "que puede [...] en

\footnotetext{
22 En los párrafos que siguen reordeno y reinterpreto el detallado relato de La Barrera (op. cit., I, pp. 9-10), que viene a coincidir con las referencias sobre "la puntual y esmerada copia que acabo de hacer para mi librería de las expresadas 62 cartas de Lope F. de Vega Carpio, con presencia ya de la de Durán, a quien devolví esta última pocos días antes de su muerte" (Notas de D. C. A. de La Barrera y Leirado a la "Vida de Cervantes" escrita por D. M. F. de Navarrete, I, Ms. 566 de la B. N. de Madrid, fol. 2 y ss) y en parte con la explicación que abre la copia de los volúmenes de cartas que cito en la nota 27, (I, fols. I-VII). En este último lugar asegura que Durán había mantenido en sigilo la existencia de su traslado "al menos para la generalidad de los curiosos". A. G. de Amezúa situaba dicho traslado "en el decenio de 1830-1840" (Epistolario de Lope de Vega Carpio, III, Madrid, 1941, pp. XVIII-XIX).

${ }^{23}$ Las referencias de A. de Schack, que extractó hasta ocho cartas, están reunidas y comentadas por A. G. de Amezúa, Epistolario, cit. III, pp. XX-XXI.

${ }^{24}$ Ya lo subrayó con acertada insistencia A. G. de Amezúa: "El hallazgo no pasó de aquí ni nadie sintió la curiosidad de abundar más en él. El único, que yo sepa, que recogió tal nueva y se sirvió de ella fue La Barrera [...] La Barrera, con su gran espíritu investigador, percatóse pronto, y más que ninguno de sus contemporáneos, del tesoro literario que contenían las cartas de Lope" (loc. cit., pp. XXII y XXIV).

25 Para un pormenorizado relato de la historia del descubrimiento de los volúmenes de cartas, véase A. G. de Amezúa, loc. cit., pp. XXIV-XXVI. N. Marín argumentó con sólidas razones que el conjunto de la colección de cartas no era tan extenso como hacía suponer la noticia de A. Durán transmitida por La Barrera ("Introducción" a Lope de Vega, Cartas, Madrid, 1985, p. 48).
} 
Riesgo y ventura de un gran bibliógrafo...

cierta manera estimarse como un facsímile"26. Y con ella en su propia casa, gracias a la autorización que le había facilitado Hartzenbusch, inició y culminó en un tiempo excepcionalmente corto "la ardua tarea de bosquejar menos imperfectamente" la vida del Fénix. La primera biografía moderna del gran dramaturgo, cuyas líneas esenciales siguen en pie aún hoy, y a la que son deudoras en grado tan amplio como inconfesado todas las posteriores, estaba terminada en mayo de $1864^{27}$.

La Barrera trabajó con febril eficacia en aquel "inestimable tesoro". Dado que en los tomos originales, además de "carecer de fecha la mayor parte de ellas", se disponían "estas cartas (salvo algún corto número) revuelta y desordenadamente", tuvo que dedicar un "afanoso estudio a su coordinación". Con los "inestimables materiales autobiográficos" que le suministraban las doscientas veinticinco cartas "escogidas, copiadas y con afanoso trabajo y estudio coordinadas" adquirió un poderoso hilo de Ariadna para moverse por los vericuetos interminables de la creación literaria de Lope ${ }^{28}$. El "prolijo

26 El traslado de I. Rosell se terminó en el mismo año 1863, según la fecha que consta en los actuales Mss. 1200-1202 de la B. N. de Madrid. Otra copia hecha directamente de los originales por un amanuense profesional y bajo la dirección de los hermanos Fernández Guerra se concluiría en 1868. Una valoración ajustada de ambas trae A. G. de Amezúa, Epistolario cit, III, pp. XXVIIXXVIII y LII-LIII, quien argumenta también la superioridad de La Barrera a la hora de interpretar o corregir equivocaciones como la fecha de la segunda carta conservada (Lope de Vega en sus cartas, cit., I, pp. 277-278). De su labor de fechación y ordenación como "ímprobo trabajo, afanoso estudio" se mostraba complacido en la advertencia preliminar a su colección, indicando que "toda mi diligencia no ha bastado, sin embargo, a descubrir en cincuenta y dos de las cartas indicios o datos que puedan aprovecharse para fijar o conjeturar aproximadamente los años en que fueron escritas".

${ }^{27}$ Lo que no siempre ha sido reconocido por los biógrafos más modernos de Lope, empeñados en señalar errores puntuales del erudito del XIX. El juicio más ecuánime sobre la Nueva biografía se debe a F. A. de Icaza, tras declararla "punto de partida de toda investigación". Indica cómo es de admirar "la discreción con que, sustrayéndose al tradicional respeto con que hasta entonces se tuvo el relato de Montalbán, señaló La Barrera las contradicciones que lo hacían inadmisible, y entresacó de la obra lírica y de las dedicatorias de las comedias de Lope lo que podía considerarse como confesiones autobiográficas, separándolo de lo que no era sino invención y culto de la propia leyenda". Y tras lamentar el retraso de su publicación hasta más de un cuarto de siglo después de escrita, razonando sobre el natural proceso por el que cada vez puede parecer "mucho más incompleta de lo que fue en su tiempo", concluye: "Para estimar en justicia el valiosísimo trabajo de La Barrera hay que pensar [...] en lo confuso y contradictorio de los datos de que disponía. Más que censurarle por sus muy explicables equivocaciones, admirará que algunas veces se aproxime a lo cierto y otros señale los puntos por dilucidar y los documentos que deben buscarse para ponerlos en claro"'" (Lope de Vega, sus amores, sus odios y otros estudios, México, 1962, pp. 12-13).

${ }^{28}$ El material ahí aludido se corresponde con los dos tomos que por regalo de F. Asenjo Barbieri se encuentran depositados en la Biblioteca de Menéndez Pelayo bajo el título Cartas de Lope Féliz de Vega Carpio. Escogidas, coordinadas $i$ anotadas por D. C. A. de La Barrera $i$ Leirado. Una minuciosa descripción de los mismos traen M. Artigas y E. Sánchez Reyes, Catálogos de la Biblioteca de 
examen de las obras todas del insigne escritor" (y no hay ni un ápice de hipérbole en la aseveración del bibliógrafo) le rindió a esa nueva luz otro "considerable número de interesantísimos datos". En la carta a Borja Pavón de 12 de agosto de 1866, donde le cuenta a éste "los trabajos que me han ocupado", rememora el proceso de escritura de la biografía con interesantes precisiones. Una espesa sombra de desaliento se proyecta ya sobre la viabilidad de poder publicar su revolucionaria investigación: "Con presencia y empleo de la preciosa colección de tres volúmenes de cartas autógrafas de Lope al Duque de Sessa, descubiertas en el archivo de este magnate en 1863, he escrito una Biografía nueva y completa de aquel Fénix de los ingenios [...] Gran parte de las cartas forman una autobiografía que íntegra está engastada en mi trabajo, y con el auxilio de ellas y la lectura detenida de dichas obras he descubierto un tesoro de datos y noticias. He sacado la partida bautismal de Antonia Clara, hija de Lope y de doña Marta de Nevares Santoyo, con quien estuvo en adulterinas relaciones desde 1616 hasta pocos años antes de su muerte ${ }^{29}$. Esta obra mía, ya

Menéndez Pelayo. I. Manuscritos, Santander, 1957, pp. 179-192. Las cartas están copiadas unas por La Barrera y otras por su amigo Vicente García Villanueva. Hasta el fol. 169 del volumen primero van anotadas, y a partir de ahí sigue a cada carta una hoja en blanco, según costumbre del bibliógrafo que manifiesta su propósito inicial de completar la anotación. Con posterioridad, pues se fecha en marzo de 1865, cuando ya había concluido la biografía de Lope, La Barrera escribió una advertencia preliminar donde explica los criterios de su selecta. Abarca -dice- "casi todas las cartas que llevan la fecha expresa; todas las que ofrecen noticias, datos o indicios para la biografía de Lope o bibliografía de sus obras; las que presentan iguales circunstancias relativas a escritores, personajes notables y sucesos históricos; y por último, todas las que, escritas por él, ya antes, ya después de su clericato, muestran con libres y desenfadados rasgos la profana soltura de sus costumbres". Es significativo que para estas fechas (y no después, como quiere A. G. de Amezúa, Epistolario, cit., III, p. LV) la dirección de la Biblioteca Nacional había acordado que la copia de los tres volúmenes de cartas hecha por Rosell dejara de ser accesible a los lectores. Así se desprende del ejemplar cierre de la advertencia: "En un país libre, celoso de sus glorias literarias e ilustrado apreciador de ellas, las cartas del Fénix de los ingenios [...] hubieran visto inmediatamente la luz pública. Aquí [...] se guardan reservadas en la Biblioteca Nacional". E incluso el más crítico y circunspecto F. A. de Icaza escribe, antes de su tremenda requisitoria contra el plagio realizado por Barbieri, que informado éste "de que el manuscrito de la Nueva biografía había sido premiado por la Biblioteca Nacional a condición de que al publicarse se suprimiera el capítulo correspondiente a sus últimos amores, así como las cartas que lo documentaban, e imaginándose que cuando se hiciera la impresión se cumpliría el atentatorio acuerdo, se apropió íntegro el dicho capítulo trasladándolo al pie de la letra sin hacer más cambio que publicar completas las cartas que en el trabajo de La Barrera se insertaban con supresiones" (op. cit., pp. 13-14).

${ }^{29}$ Que La Barrera destacara siempre esta aportación de su trabajo no da pie a pensar que dicho descubrimiento constituyera el único obstáculo que impediría publicar la biografía de Lope. Apuntando al jurado calificador de la misma lanzó la especie F. Asenjo Barbieri (escondido bajo el anagrama de José Ibero Ribas y Canfranc) en Últimos amores de Lope de Vega, revelados por él mismo en 48 cartas inéditas y varias poesías, Madrid, 1876: "Podía contribuir a rebajar el valor moral del Fénix de los ingenios considerado como hombre y como sacerdote" (pp. 9-10). Y lo repitió sin más A. G. de Amezúa: "La Barrera, con gran acierto, sírvese ampliamente de las cartas y gracias a ellas 
Riesgo y ventura de un gran bibliógrafo...

concluida, forma un tomo en folio de más de 400 hojas, escrito de esta misma letra y en este papel de mano, catalán. En otro país se iría por su pie a la imprenta [...] Pienso regalarle a la Biblioteca Imperial de París o al Museo Británico".

¿Qué obstaculizaba la publicación en España de la biografía de Lope?. Una reflexión a redropelo de Menéndez Pelayo en el momento de dar a luz varias décadas después el trabajo de La Barrera resulta elocuente al respecto: "La historia tiene sus derechos: como espejo de la fiel e incorrupta verdad aun puede sostenerse que el conocimiento de las flaquezas de los grandes hombres, cuando el correr de los siglos las descubre, más tiene de lección moral que de piedra de escándalo, en cuanto sirve para impedir que la justa admiración degenere en sacrílega apoteosis. Puesto que han llegado a nosotros tan gran número de cartas de Lope ¿quién hubiera sido osado a destruir papeles donde puso la mano el Fénix de los Ingenios? Y no destruyéndolos ¿cómo era posible estorbar, aun por medio de las reservas y ocultaciones impropias de nuestro tiempo que tarde o temprano [...] diera alguien razón del contenido de tales documentos?". Si todavía el estudioso y editor del teatro de Lope, que a esas alturas era ya bastante más irenista y tolerante que la mayoría de los eruditos de la generación anterior, tenía que recurrir a salvedades y distingos y asegurar que nada de eso "se dice para atenuar ni en parte mínima la culpabilidad" del Fénix ${ }^{30}$, ¿cómo puede extrañarnos el auténtico cordón sanitario de "reservas y ocultaciones" que se levantó alrededor de la biografía de La Barrera?. Creo que

puede reconstruir casi por entero el episodio amoroso de Amarilis, capital en la vida del gran poeta, libertad que el jurado de la Biblioteca, calificador del concurso no comparte" (Lope de Vega, cit. II, p. 6).

30 Pero en realidad sí, sobre todo cuando trata de justificar por "la moralidad corriente y harto laxa de su tiempo" lo que a su entender ha sido "abultado y exagerado por la malicia": "El hecho desgraciadamente cierto de haber puesto Lope su pluma y su divino ingenio al servicio de las pasiones del Duque de Sesa". O cuando añade, con inaceptable comparación, que hay que entenderla como una "especie de tercería literaria", sin nada que ver "con otras más vulgares y deshonrosas tercerías", y esa "la ejerció sin escrúpulo un tan principal y cumplido caballero como Garcilaso, escribiendo las bellísimas estrofas de La Flor de Gnido" (op. cit., II, p. 182). Además el polígrafo se permitió justificar la inclusión de tres poemas de la hija de Lope, sor Marcela de San Félix, "para que el fervor espiritual y la pureza mística de estos versos temple y dulcifique la impresión penosa y amarga que no pueden menos de dejar en el espíritu algunos rasgos de la vida moral del Fénix de los Ingenios ( (pp. 173-176). Por otra parte, como reconoce A. G. de Amezúa al referirse a la comparación con Garcilaso como un propósito loable de "exculparle [a Lope] siquiera parcialmente de esta infamante nota", Menéndez Pelayo no abandonó del todo el terreno de la reprobación moral. Y cita al propósito un texto de 1905 en que el maestro santanderino afirmaba que " el gran poeta sirvió al Duque de Sessa demasiado en sus pecaminosos empeños" (Lope de Vega en sus cartas, cit., I, p. 390). 
la carta antecitada apunta al menos en una dirección. Más que la posibilidad misma de regalar el fruto de sus vigilias a las Bibliotecas nacionales de Francia e Inglaterra marcaba el desideratum final la exclusión de la Nacional de Madrid como un destino adecuado. En la comunicación de los primeros materiales y en franquear el uso y disfrute a La Barrera de la copia oficial destinada a dicho establecimiento de la totalidad de las cartas, J. E. Hartzenbusch había actuado con su positivo respaldo. Pero no debió ser idéntico el comportamiento y el parecer del director de la Biblioteca Nacional cuando llegó a conocer los derroteros que el nuevo fondo documental imponía a la biografía del Fénix. Muy pronto empezaría a fraguarse la leyenda negra en torno a una investigación inoportuna y transgresora: dañina para una gloria de las letras españolas, podía salpicar de alguna forma con el escándalo al conjunto de éstas. Hierofante de la conjura silenciosa en un primer momento fue el mismísimo Hartzenbusch.

Hay un error inexplicable como simple lapsus en la semblanza que el autor de Los amantes de Teruel trazó de La Barrera. Habiendo formado parte del tribunal que juzgó el concurso bibliográfico de la Biblioteca Nacional en fecha tan cercana como 1866 tergiversa su resultado al considerar que fueron objeto de premios distintos el Catálogo adicionado y corregido y la biografía de Lope. A ésta la identifica incluso materialmente ("forma un grueso volumen en cuarto") y la define con cierta displicencia como "repertorio general de noticias acerca del Fénix de los ingenios y de muchos contemporáneos". Pero de aquél insinúa que fue él mismo quien animó a su autor a rehacerlo para participar de nuevo en el prestigioso concurso: "Oyendo dócilmente avisos amistosos que se le dirigieron, y no cesando en el digno empeño de perfeccionar su obra, volvió a presentarla cuajada de adiciones y enmiendas muy oportunas, y obtuvo por ellas otro premio también de esta casa". Gracias a la documentación sobre el evento conservada en el Archivo de la Biblioteca Nacional puede precisarse punto por punto lo realmente ocurrido ${ }^{31}$. Sin duda La Barrera quiso aprovechar las

\footnotetext{
31 En la carpeta Sig. 0393, Doc. 03. que por su interés para iluminar definitivamente la cuestión he decidido reproducir en el "Apéndice documental" en todo lo concerniente a la obra de La Barrera. Especialmente significativos resultan los cambios redaccionales en el borrador del acta de 28 de diciembre de 1866, al recoger las observaciones que Hartzenbusch como presidente hizo a la "demasiada desnudez" de la Nueva biografía de Lope. Un buen resumen del mismo realiza J. Delgado Casado (op. cit., I, pp. 236-239). Aunque sin haber manejado el documento, A. G. de Amezúa reflexionaba de forma verosímil sobre los efectos contradictorios que creó la decisión del jurado calificador: de una parte, consolidando "una atmósfera por extremo desfavorable para el buen nombre de Lope"; de otra, espoleando "la curiosidad malsana de eruditos y literatos para conocer lo que de verdad hubiese en el fondo de tales rumores que cada vez crecían y se propagaban más" (Lope de Vega, cit., II, p. LV). A "la mojigatería del jurado que examinó la biografía" se refiere también, sin conocimiento detallado del conflicto episodio, F. A. de Icaza,
} 
Riesgo y ventura de un gran bibliógrafo...

facilidades que se le habían prometido a su Catálogo renovado para intentar sacar del atolladero a su flamante biografía de Lope. En su escrito de presentación, que se fecha el 25 de noviembre de 1866, consideraba que la Nueva biografía (titulada Crónica biográfica y bibliográfica de Lope), cuya base documental explica en términos similares a los ya citados, debía ser contemplada como un "Apéndice" del Catálogo mismo. Esta hibridación de dos obras de tan diferente alcance y método no logró escamotear la artificiosidad del conjunto presentado, ni distraer la atención del jurado de lo que sería a la postre el verdadero punto dolens del debate: la licitud o no de publicar y en qué forma la biografía de Lope. Determinados pasajes de las cartas transcritas, pese al "esmerado trabajo en que lucen la profunda erudición, sana crítica y otras dotes literarias del Sr. Barrera", resultaban demasiado ofensivos al decoro y las buenas costumbres como para aparecer tal cual en letras de molde, según el severo juicio de Hartzenbusch. Finalmente, y con un efecto contrario al que quiso propiciar su autor, la biografía arrastró consigo al Catálogo. Como detalla el extenso informe firmado por P. de Gayangos el 28 de diciembre de 1866, la única salida razonable, ateniéndose al reglamento, era que una obra ya premiada, pese a su profunda reelaboración, no podía serlo por segunda vez, proponiéndose como alternativa al ministerio de Instrucción Pública la adquisición de los originales de La Barrera. Una segunda propuesta del 25 de enero de 1867 llevaría a término el tribunal, a instancias del propio ministerio, fijando en 800 escudos -la misma monta del premio- la compra de ambos manuscritos.

La Barrera tuvo conocimiento detallado de las deliberaciones y enfrentamientos ocasionados por su obra. En carta a Borja Pavón del 17 de agosto de 1868 vuelve a explicarle el proceso de su conocimiento y estudios de las cartas de Lope ("billetes de interior en su mayoría") y todo lo que a través de ellas había descubierto de sus amores y tercerías, para terminar recordando cómo "el tribunal que en 1866 decretó la adquisición y publicación de dicha obra por cuenta del gobierno desaprobó por solo un voto de mayoría el dictamen del ponente Sr. Gayangos que proponía la completa publicación de mis descubrimientos y por consecuencia se me mandó que al imprimir la obra suprimiera lo que ya Vd se figurará con los antecedentes enunciados"32. Ya en ese

apuntando luego a lo que denomina expresivamente "la curiosidad de escándalo que revolvió las cenizas del Fénix" (op. cit., pp. 14 y 75).

32 Merece ponerse de relieve la coherencia de P. de Gayangos en todo este asunto. Ya en una nota de la edición castellana del Ticknor referida a la colección de cartas de Lope había indicado que "aunque su importancia no es tanta como pudiera creerse, es lo bastante para desear que se publiquen" (Historia de la literatura española, II, Madrid, 1851, p. 558). ¡Lejos estaba de prever que la edición se dilataría casi un siglo como efecto de ese debate en el que a él le correspondió el difícil papel de vocero derrotado por la estrechez puritana con tintes -y poder de censura- cuasi inquisitoriales!. 
momento parece haberse plegado a las imposiciones de una censura moral decretada por colegas de profesión a los que nada cuadraba la imagen de templanza y equilibrio con que los retrató Menéndez Pelayo, calificándolos de "gente por lo común madura y curtida". Según A. G. de Amezúa, "accedió La Barrera, aunque malhumorado y por fuerza a tal acuerdo, quedando su obra archivada"33. Lo cierto es que en la carta de 21 de junio de 1868 consideraba entre sus ya menguadas tareas la del "perfeccionamiento del manuscrito de esta Biografia". Un perfeccionamiento que hay que entender en el sentido material de nueva puesta en limpio con el pulcro caligrafiado del manuscrito definitivo, y también en el de proceso conducente al texto que se publicaría abriendo la edición académica del teatro de Lope, con la poda de "algunos pasajes demasiadamente libres que le parecieron no cuadrar al severo tono de un libro de erudición, por grandes que sean los ensanches que a la erudición se concedan", en palabras de su editor ${ }^{34}$. Mientras tanto, difundidos en un círculo cada vez más amplio los rumores sobre el contenido amatorio de las cartas y las mismas tercerías de Lope, ocurrió, en palabras del polígrafo, lo que "tenía fatalmente que suceder": que llegaron a ser del dominio público "en la forma más ruidosa por lo mismo que se había querido huir de la más natural y menos ocasionada a peligros". Para alguien tan reacio a publicitaciones y enemigo de escándalos como La Barrera el efecto debió ser demoledor. En la citada carta de agosto se nos descubre inerme y a la vez exasperado por la acogida de "estas historias de Lope y mías que han ocupado ya a los periódicos extranjeros". Y desfondado, por una vez parece estar a punto de rendirse a la axfisia ambiental, interiorizando hasta un término extremo el veredicto de censura: "Mi íntimo y vivo deseo en este asunto es que mi obra no se imprima".

Poco cambiarán las cosas en la vida de La Barrera. Debió tener clara conciencia del valor acrecido, si cabe, de sus investigaciones ante el desastre que hizo desaparecer a partir de 1869 el archivo de Altamira ${ }^{35}$. Pero asistió también al interesado y vergonzante silencio, digno de figurar en los más negros anales de la cultura española durante la centuria decimonónica, con que quedó envuelta su generosísima oferta pública: "He escrito y tengo concluida [...] una Nueva biografía de Lope de Vega y Carpio (volumen de más de 400 hojas en folio) que regalaré sin condición alguna a cualquier editor que se comprometa a

\footnotetext{
33 A. G. de Amezúa, Epistolario, cit., III, p. LV. No encuentro fundamento al aserto del mismo estudioso acerca de "la resitencia de La Barrera a franquear la parte descartada de la obra".

${ }_{34}$ M. Menéndez Pelayo, "Adiciones [...]", en op. cit., II, p. 182. El original definitivo de la Nueva biografía se encuentra en el Ms. 20201 de la Biblioteca Nacional.

35 Un excelente relato de ese desastre, con la localización actual de los tres volúmenes que restan del epistolario de Lope se hallará en N. Marín, "Introducción", cit., pp. 48-49 y 53-54.
} 
Riesgo y ventura de un gran bibliógrafo...

publicarla"36. Una conjura silenciosa y de facto un sepultamiento que pudo ser, si no definitivo, bastante más prolongado de no mediar la apuesta admirativa de Menéndez Pelayo ${ }^{37}$. Rescate cumplido cuando la pleamar del escándalo había descendido bastante, aunque no lo suficiente como para que el polígrafo se atreviese a restituir cuanto exigía la verdad histórica, callando "por respeto a la memoria de Lope y a sus mismos lectores, gran número de pasajes y cartas enteras donde la pluma libertina y desenfadada del poeta había corrido sin freno ni escrúpulo"38.

\footnotetext{
36 En Poesías de D. Francisco de Rioja corregidas con presencia de sus originales. Añadidas e ilustradas con la biografía y la bibliografía del poeta por D. Cayetano Alberto de La Barrera y Leirado, Madrid, 1867, p. 105.

37 Menéndez Pelayo tuvo conocimiento de "la biografía inédita de Lope escrita por La Barrera y Leirado, que existe en la Biblioteca Nacional" a través de una carta de Gumersindo Laverde que se data en marzo de 1876, y a la que contesta tres días después: "Excelente libro será el de La Barrera ¡Lástima que no se publique!" (Epistolario de Laverde Ruíz y Menéndez Pelayo. 1874-1890, I, Santander, 1967, pp. 361-366). Pero en 1871, L. Fernández Guerra había aprovechado la veta en su conocida biografía de Juan Ruíz de Alarcón con "tantas y tan explícitas revelaciones [...] sobre los puntos más delicados de la vida de Lope" (M. Menéndez Pelayo, "Adiciones [...]", II, p. 181) El joven polígrafo se interesó vivamente por la biografía, considerando que C. Rosell (que formó parte del tribunal de 1866 y había sucedido a Hartzenbusch en la dirección de la Biblioteca Nacional) no contaba con razones de "fundamento [...] para no publicar el libro de La Barrera": "Malo es que las tercerías y embrollos de Lope -continúa en su carta de abril de 1876- no se hayan librado de las escudriñadoras miradas de la posteridad, pero, ¿a qué ocultarlos, cuando son bien conocidos de los eruditos desde el hallazgo de sus cartas al duque de Sessa y cuando ya les ha dado harta publicidad Fernández Guerra?". La respuesta de Laverde resulta taxativa: "Tiene Vd. razón en lo que dice sobre los motivos de no publicarse la vida de Lope de La Barrera. El mal ya está hecho y no tiene remedio, y además la historia es historia". Un mes después veía la luz el libro de F. Asenjo Barbieri, merecedor de dos comentarios en vivo de Menéndez Pelayo en sendas cartas de junio: "De poco ha servido que la Biblioteca Nacional esconda el Lope de La Barrera"; "Si se hubiese publicado íntegro el libro de Barrera, nadie habría parado mientes en este episodio. Por evitar un mal, ha resultado otro peor" (Epistolario, cit., pp. 371, 373, 421 y 428).

38 A. G. de Amezúa, Lope de Vega en sus cartas, cit., II, p. 7. Juicio significativo por provenir de quien daba a conocer completo el epistolario de Lope medio siglo después de aparecida la Nueva biografía. Y lo hacía con tal cúmulo de distingos pudoris causa y tal batería de denuestos y pullas contra el oficio de secretario de Lope y sus cartas de tercerías amatorias que nos permiten imaginar el ambiente en que se fraguó la censura y posterior enclaustramiento de la obra de La Barrera. No me resisto a espigar unas muestras del incontinente desafuero verbal: "Escándalos, imprudencias, verdaderas locuras [...] torpe lujuria, concupiscencia baja, libertinaje franco, lascivia física, vulgares adulterios [...] hedentina lujuriosa [...] torpe e inmoral asesoramiento [...] asistencia pecadora y mefistofélica" (op. cit., I, pp. 320, 342, 347, 369 y 369).
} 
José Lara Garrido

\section{Precisiones acerca del magisterio de B. J. Gallardo: débito y homenajes}

Tan especioso como gratuito me parece el dilema suscitado en fechas recientes acerca de si existió o no una escuela de Gallardo ${ }^{39}$. Insostenible, desde luego, es el enfoque improvisado por P. Sáinz Rodríguez asegurando que "la ideología de Gallardo fue conquistando a muchísimos eruditos e investigadores de su época; a éstos, a los que no se atrevían a las ligerezas de Quintana, son a los que podemos calificar de escuela de Gallardo, puesto que fue éste quien aportó los principios y los difundió. Muchos de estos eruditos fueron verdaderos discípulos, amigos, instruidos por él en los secretos de la erudición". ¿Cuáles fueron los "principios", y exactamente dónde está esa supuesta falange de seguidores que los practicaron? La respuesta tangencial del estudioso Gallardo no puede resultar más inconsistente, al reducirlo todo a la "ortografía peculiar" del bibliógrafo extremeño que como "un síntoma de sumisión a su autoridad" y "el sello de la máxima intimidad" practicaron La Barrera "y el padre de los Fernández Guerra, don José Fernández Guerra, que no sólo utilizaba esta ortografía sino que publicó una comedia, In contra el viento, con arreglo a sus normas" 40 .

En realidad, Gallardo sólo tuvo un verdadero discípulo, que no fue otro que Cayetano Alberto de La Barrera. Y no tanto porque él declarase los específicos débitos a su magisterio o sostuviese -con mayor flexibilidad y pragmatismo- parecido sistema ortográfico ${ }^{41}$; ni siquiera por ser, en palabras de

39 "Por esos años se estaba produciendo ya la renovación total de la crítica literaria española [...] Si las primeras formulaciones teóricas de esta nueva aproximación histórica y crítica a los textos antiguos se deben a don Bartolomé José [Gallardo], si éste puso las bases de la nueva ciencia bibliográfica en que se había de basar la investigación filológica y literaria moderna [...] no creó escuela como tal" (M. Sánchez Mariana, "La recuperación de la literatura española en el siglo XIX: antologías y colecciones. La investigación y la edición de textos", en AA. VV. Historia de la literatura española, IX, Madrid, 1998, p. 851). Estoy básicamente de acuerdo con el dictamen. Y en ese sentido creo que habría que reducir a la singularidad que explico a continuación lo afirmado en otro lugar por el mismo Sánchez Mariana, cuando califica a La Barrera de "uno de los más fieles discípulos de Gallardo y de los más notables bibliógrafos del XIX" (Bibliófilos españoles, Madrid, 1993, p. 232).

40 P. Sáinz Rodríguez, Historia de la crítica literaria ... cit, p. 212. Claro es que en un sentido lato, "la mayor parte de las fuerzas vivas de la erudición decimonónica [...] directa o indirectamente, son discípulos de Gallardo" (J. M. Rozas, Los períodos de la bibliografía literaria española, Cáceres, 1983, p. 26).

41 Ya Hartzenbusch aseguraba que la ortografía de La Barrera era "la misma que usó el difunto D. Bartolomé José Gallardo", lo que desde entonces acá se ha venido repitiendo. Pero el asunto requeriría un análisis particular, donde se considerase las afirmaciones del primero sobre la necesidad de limitar el uso del nuevo sistema ortográfico y no emplearlo, por ejemplo, para las transcripciones bibliográficas o de textos, expuestas en su informe sobre el Ensayo al que me referiré luego. Al publicar la Nueva biografía de Lope aludía con exactitud M. Menéndez Pelayo a la "ortografía un tanto singular que La Barrera usaba en sus manuscritos (aunque no en sus 
Riesgo y ventura de un gran bibliógrafo...

Sáinz Rodríguez, "verdadero fanático de Gallardo que reunió materiales copiosísimos para su biografía". Lo fue en razón de haber resultado el único capaz en su momento de entender que la multifacética actividad desplegada en los campos de la bibliofilia y la bibliografía por el autor del Ensayo estaba destinada a desembocar en una historia literaria de calidad y calado distintos a las hasta entonces practicadas. Y el único que, con absoluta consecuencia, no dudó en arrostrar sacrificios de similar índole hasta trazar el reticulado de otras parcelas de la literatura española con vistas a servir para idénticos objetivos. Quizá no haya mejor vía de entender esa asumida comunidad continuadora de un camino abierto que al trasluz de la ambigua actitud con que La Barrera recepcionó la primera historia literaria de España, una obra que en parte cumplía y en parte defraudaba, al aligerarlo, el programa de Gallardo: la del hispanista norteamericano G. Ticknor ${ }^{42}$. La sombra del magisterio gallardiano se yergue todavía en la declaración que inicia la última de las investigaciones completadas por La Barrera. En ella vino a reivindicar la cualidad más allá de lo instrumental de las labores biobibliográficas, vistas como fundamento tanto de las ediciones de los clásicos como de una historia literaria nacional. Veteándolo con las críticas lamentaciones de quien debía sentirse poco menos que realizando una apuesta en solitario: "La historia literaria, menos afortunada en nuestra España que la política, a pesar de su amenidad y de la riqueza y gloria de los timbres con que en su inmenso campo se ostenta adornado el ingenio español, ha sido entre nosotros escasa y limitadamente cultivada. Si de sus ramas principales, la crítica aparece aquí tratada e ilustrada por muchos y muy insignes escritores, en la biografía y la bibliografía ${ }^{43}$ no contamos conocidamente

ediciones), ortografía idéntica en lo sustancial a la de su maestro D. Bartolomé José Gallardo" (op. cit., II, p. 187).

42 La obra de Ticknor fue una cruz y un desafío para la actividad investigadora de La Barrera. Nunca dejó de tenerla en cuenta ni nunca desaprovecharía ocasión para señalarle errores $u$ omisiones, viéndola en cierto modo como fruto en agraz, como un gran edificio sin suficiente cimentación biobibliográfica. Considero del mayor interés al respecto las anotaciones que La Barrera puso en su ejemplar de la traducción española adicionadas por P. de Gayangos y E. de Vedia (Madrid, I-IV, 1851-1856) estante en la Biblioteca Nacional (INV 860 Tic). Habiendo pasado desapercibidas hasta ahora, dichas notas han merecido la edición y estudio que lleva a cabo B. Molina Huete, "Una partida de erudición con Gallardo al fondo: Las notas inéditas de Cayetano Alberto de La Barrera a la Historia de la Literatura español de G. Ticknor», incluido en este mismo volumen de Lectura y Signo, pp. 225-268.

43 En realidad, como ocurría con Gallardo, la bibliografía era concebida con la complejidad y alcance propios de una labor filológica que abría camino a la edición de textos y a su valoración crítica. El énfasis de La Barrera en la biografía se explica, desde su pertinencia heurística como soporte preciso de la bibliografía. En tal sentido, justificaba así su "afición a las indagaciones biográficas": "La necesidad misma de aclarar con su auxilio las infinitas dudas acerca de los verdaderos autores [...] me llevaron como por la mano a la más ardua tarea de escribir al frente de cada repertorio una puntual noticia de la vida y obras del autor respectivo. $\mathrm{Y}$ al mismo tiempo 
sino algunos, muy distinguidos a la verdad, pero que no han podido abrazarla con la extensión y perfección apetecibles, ya porque abarcando demasiado, como el ilustre D. Nicolás Antonio, habían de ser forzosamente diminutos y a menudo inexactos, ya porque su objeto fue, como debía, circunscribirse en sus trabajos a un radio determinado. Si nuestra biografía literaria y nuestra bibliografía hubieren sido en España debidamente apreciadas, no veríamos impresos y reimpresos muchos de nuestros autores clásicos, célebres en todo el orbe, con mezquinas y descuidadas ilustraciones, y algunos absolutamente faltos de toda noticia, de todo esclarecimiento de esta especie" 44 .

La relación de Gallardo y La Barrera fue abordada de forma puntual en varias ocasiones por A. Rodríguez Moñino. Indicó en una de ellas cómo éste "conoció y trató" al autor del Ensayo "aunque no fue siempre cordial su comunicación", y cómo coleccionó de él y sobre él "un arsenal insustituible y una cantera de materiales de primera mano", lamentando que no llegara a escribir su biografía ${ }^{45}$. En efecto, son frecuentes las alusiones admirativas de La Barrera a Gallardo, al que no rebaja nunca, cuando se refiere a su labor, de los apelativos de "insigne" y "eminente bibliógrafo"46. Tampoco faltan incidentales reproches a su desenvuelta lengua y aspereza crítica, llegando a llamarlo, al evocar su facilidad para el motejo, "el bellacón de D. Bartolomé José" (carta de

convencido de cuanto ganaría mi tarea en ilustración y autoridad si en ella se expresaban los orígenes a que debía su fundamento, me decidí a redactarla bajo un plan completamente bibliográfico" (Catálogo bibliográfico y biográfico del teatro antiguo español, desde sus orígenes hasta mediados del siglo XVIII, Madrid, 1860, p. V).

44 Poesías de D. Francisco de Rioja corregidas con presencia de sus originales. Añadidas e ilustradas con la biografía y la bibliografía del poeta por D. Cayetano Alberto de La Barrera y Leirado, Madrid, 1867, p. V. En más de una ocasión se quejó amargamente La Barrera de que los críticos desatendieran las investigaciones de los bibliógrafos. Resulta expresiva la lamentación a propósito de unas afirmaciones sin fundamento realizadas por C. Rosell en contra de los datos que figuraban ya en el Catálogo biográfico y bibliográfico: "Al leer este párrafo he acabado de convencerme de cuan inútilmente nos cansamos los bibliógrafos y biógrafos y gastamos el tiempo, puesto que nuestras tareas ni sirven para la generalidad del público ni para los señores doctores en ingenio [...] En vista de que no se me pedían [los textos citados en el Catálogo, entre ellos "el ms. que poseo de $\mathrm{La}$ Numancia"] he tenido por conveniente el reservarlos, tomando así en cierto modo justa revancha del desdén con que se reciben esta clase de tareas histórico-literarias" (Notas de D. C. A. de La Barrera y Leirado a la Vida de Cervantes escrita por D. M. F. de Navarrete, II, Ms. 567 de la B. N. de Madrid, fols. 94-96).

45 A. Rodríguez Moñino, Don Bartolomé José Gallardo (1776-1852)... cit, pp. 13-14. Una carta de Gallardo a La Barrera fechada en Córdoba en 1841 fue dada a conocer por el mismo estudioso en "Grandes bibliófilos españoles. D. Bartolomé José Gallardo. Noticias y recuerdos inéditos, por D. Cayetano Alberto de La Barrera", en Bibliofilía, IV (1951), pp. 25-26. Otra de La Barrera a Gallardo, de 1843, se encuentra en la Biblioteca de Menéndez Pelayo (M. Revuelta Sañudo et alii, Catálogoinventario de los manuscritos y papeles de la Biblioteca de Menéndez Pelayo [Segunda Parte], Santander, 1994, p. 118).

${ }^{46}$ Así en El Cachetero del Buscapié, cit., pp. 6 y 60. 
Riesgo y ventura de un gran bibliógrafo...

1865). Pero ese distanciamiento exigido por los hábitos y corte temperamental de quien, dado su carácter afable y extremada cortesía, era en cierto modo la antítesis del erudito extremeño, no obsta para que La Barrera defendiese con infatigable ardor la integridad ideológica y la labor hercúlea de Gallardo. Hasta el punto de verse envuelto, por conducirse con una extremada fidelidad a su memoria, en la turbulenta polémica del Buscapié, ante "el silencio que guardaron nuestros jóvenes y eminentes ingenios, abandonando en el palenque al anciano Gallardo"47. Y defendió por supuesto, frente a la conjura solapada con la que los enemigos del erudito la redujeron a leyenda, la realidad de sus desastres y cataclismos bibliográficos, de los que tuvo aquél que sobreponerse para poder rehacer en parte una obra ingente: "Y a la duda que se afecta abrigar respecto si Gallardo se valía de este pretexto para superponérsele autor de soñadas obras, puede contestarse con los admirables trabajos que de su pluma y fruto de sus continuados estudios se han encontrado y en parte se están imprimiendo"48.

"No me han ocupado nunca seriamente acerca de los modernos escritores de todo género otros estudios bibliográficos que los relativos a Gallardo", confesaba a Borja Pavón en 1865. Para esas fechas ya tenía reunidos La Barrera el conjunto de materiales biobibliográficos que se reparten ahora entre dos volúmenes de la Biblioteca Menéndez Pelayo y un tercero de la Biblioteca Nacional ${ }^{49}$. Contienen dichos volúmenes el entramado de la biografía, un completísimo catálogo de su obra impresa en vida de Gallardo y la reunión del conjunto casi completo de sus opúsculos y folletos (algunos de extremada rareza, como los impresos en Cádiz a partir de 1811, incluyendo también determinadas réplicas a Gallardo). Instrumentos preciosos, que han servido de guía inexcusable a los estudiosos modernos del autor del Ensayo, sin que ninguno de ellos hasta llegar a A. Rodríguez Moñino lograra un conocimiento tan preciso y contundente de la novedad del legado bibliográfico gallardiano como el que tuvo La Barrera. Daré aquí una prueba categórica. Con ocasión de valorar el impacto causado por el inicio de la publicación del Ensayo escribía

47 Notas de D. C. A. de La Barrera y Leirado a la Vida de Cervantes escrita por D. M. F. de Navarrete, I, Madrid, 1852, Ms. 566 de la B. Nacional de Madrid, fol. 2a.

48 Notas de D. C. A. de La Barrera, cit., I, p. IV. El pasaje no escapó a la diligencia de A. Rodríguez Moñino, quien lo cita oportunamente en Historia de una infamia bibliográfica. La de San Antonio de 1823. Realidad y leyenda de lo sucedido con los libros y papeles de don Bartolomé José Gallardo, Madrid, 1965, p. 28.

49 Los tres volúmenes llevan el ex-libris "Librería del Licenciado D. Cayetano Alberto de La Barrera" (una reproducción fotográfica del de la Biblioteca Nacional trae M. Sánchez Mariana, Bibliófilos..., cit., p. 232) Los de la Menéndez Pelayo se titulan Noticias biográficas de D. Bartolomé José Gallardo. Catálogo de sus obras impresas. Obras varias del mismo autor conexas con los sucesos de su vida y Obras varias de D. Bartolomé José Gallardo (Manuscritos M-119 y 120 de esa biblioteca en la que ingresaron por regalo de F. Asenjo Barbieri. Véase M. Revuelta Sañudo et alii, op. cit., p. 79). El de la Biblioteca Nacional se rotula en el lomo Obras varias de Gallardo y tiene la signatura R-420. 
Rodríguez Moñino que con esta obra "se renueva por completo el concepto de la bibliografía literaria hispánica": "Fruto de muchos años de una vida inteligente y laboriosa, consagrados a penetrar en los más recónditos arcanos de la erudición [...] vino a transformar un concepto de bibliografía-catálogo, que se arrastraba desde los tiempos de Nicolás Antonio, para convertirlo en bibliografíaflorilegio, en la que se presenta al lector el meollo y la sustancia de lo que le interesa en el libro"50. Lo mismo exactamente y en términos muy parecidos había resaltado La Barrera en su carta de 26 de enero de 1865: "Muy lejos se hallan de ser un esqueleto los trabajos bibliográficos del célebre erudito y hablista. Constan de más de cinco mil papeletas que a su riqueza de datos bibliográficos y biográficos reúnen un tesoro de materiales antológicos, principalmente de poesía. Ya puede Vd. observarlo en el tomo publicado que de hecho es un Cancionero [...] En manos de Gallardo no era la bibliografía un árbol seco y despojado".

En 1861 La Barrera fue nombrado vocal del certamen de bibliografía patrocinado por la Biblioteca Nacional y le correspondió, por delegación del jurado, el examen y posterior informe acerca de las dos obras presentadas, "una sin título alguno, comprensiva de noticias biobibliográficas de médicos españoles [...] la otra con el proyectado epígrafe Ensayo de una biblioteca, o bien Diccionario bibliográfico de libros antiguos españoles raros y curiosos"51. Su valoración de los materiales de Gallardo comenzaba con un sentido ejercicio de excusatio humilitas: "La superficialidad y escasez de mis conocimientos no me da a la verdad títulos ni derecho para constituirme en juez de tal autor ni de tales escritos". Entreveraba, potenciando las supuestas limitaciones, una pudorosa confesión que a juicio de La Barrera venía a lastrar su imparcialidad: "Las antiguas relaciones de amistad que tuve con el Sr. Gallardo (a cuyo trato debo muy principalmente mi afición a esta clase de tareas)". Pero teniendo que aceptar "el encargo que se me confió", y desinhibiéndose frente a cualquier tipo de mal fundada sospecha con el atento examen y desestima de la primera de las obras presentadas a concurso, aprovechó la ocasión para trascender los límites y el calado de un simple dictamen. Con ecuanimidad no exenta de brillante determinación, La Barrera trazaba un balance valorativo insuperado de lo que iba a suponer para la bibliografía española el futuro Ensayo: "La obra de D. Bartolomé José Gallardo, aumentada y ordenada, abraza en su copiosos

\footnotetext{
50 A. Rodríguez Moñino- M. Brey, "Advertencia preliminar", en Catálogo de los manuscritos poéticos castellanos de The Hispanic Society of America, III, Nueva York, 1966, pp. 24-25.

51 Según figura en dicho dictamen, que con el encabezamiento "Al tribunal de premios literarios de la Biblioteca Nacional de Madrid para el concurso de 1861" y firmado el 19 de diciembre se recoge en el expediente que conserva el archivo de la Biblioteca Nacional (Sign. 0391, Doc. 01). Son cuatro hojas escritas por recto y vuelto, salvo la última que lo es sólo por el anverso. De ellas extraigo las citas que a continuación resalto y comento.
} 
Riesgo y ventura de un gran bibliógrafo...

contenido varias monografías muy completas, entre ellas señaladamente las de antiguos libros españoles de medicina, poesía y novela". Marcaba también en esos materiales el gradiente biobibliográfico preconizador de su propio método: "Encierra un riquísimo caudal de preciosos datos y apuntes para las vidas de los autores [...] además incluye considerable número de biografías ilustradas con documentos y testimonios hasta el día de hoy enteramente desconocidos". Y como telón de fondo dibujaba el admirativo perfil de una trayectoria vital encauzada hacia una titánica tarea cuyos resultados, aunque parciales y fragmentarios, sólo podían producir estupor: "La incansable laboriosidad de este erudito que desde su juventud [...] se entregó con apasionado cuanto insaciable afán a las más prolijas investigaciones acerca de los escritos y vidas de nuestros autores y a las adquisiciones de bibliófilo, y que por espacio de cincuenta años, y hasta pocos días antes de su fallecimiento, con el mismo ardoroso celo y con la misma fuerza de facultades morales y físicas, continuó acrecentando su caudal de libros y de preciosas noticias, sin perdonar gasto ni fatiga de ninguna especie; esta incesante y entendida labor había necesariamente de dar por resultado el inestimable depósito que ahora se nos ofrece para enriquecimiento de nuestra envidiada literatura".

El privilegiado conocimiento que La Barrera tuvo de las "papeletas" y el "tesoro de materiales antológicos" conjuntados en la obra facticia que obtuvo el premio de bibliografía de 1861 acreció, si cabe, su rendida devoción hacia Gallardo. Con permanente interés y desgranando un rosario de quejas contra quienes, a su certero entender, retrasaban por espurias razones la publicación de la obra, no perdonó ocasión para recalcar la singular excelencia del Ensayo. Poco antes de que el tomo primero viese la "pública luz al cabo de dos largos años de sudores y trasudores de las prensas", sancionó de nuevo en Gallardo la ecuación de vida y labor, al tiempo que las hacía inflexionar conjuntamente hacia el proyecto de una futura historia de la literatura española: "No sin asombro se han visto los trabajos con que el sabio colector labraba, sobre firme terreno, los cimientos de nuestra historia literaria. Copias esmeradas, que a menudo son verdaderos facsímiles, de manuscritos de grande importancia [...] infinidad de extractos, apuntes y florilegios de prosa y verso; prolijas anotaciones al margen de todos sus libros; la colección de cédulas bibliográficas, y una extensa correspondencia literaria, rica de noticias y pormenores, formaban las bases del edificio que aspiraba a levantar"52. Nada tiene de extraño que, por esas fechas, La Barrera terminase declarando a Gallardo "el

52 Esta reflexión de 1864 fue ya resaltada por A. Rodríguez Moñino, de quien extraigo la cita (Don Bartolomé José Gallardo, cit., p. 262). 
primer bibliógrafo de España y aun acaso de Europa"53. Y que antes y después prodigara como timbre y blasón de su propia trayectoria haber contribuido decisivamente a allanar el triunfo de la obra mayor amparada por el nombre "del insigne erudito y aventajado filólogo don Bartolomé José Gallardo, mi antiguo y apreciado amigo"54.

El medio natural de un bibliógrafo es la biblioteca. La Barrera, como Gallardo, sintió desde muy joven una incontenible pasión por las bibliotecas como depósitos inagotados, filones de deslumbrantes tesoros. Se conservan unas páginas de apuntes suyos, realizados con anterioridad a 1850, acerca de grandes bibliotecas y hallazgos bibliográficos de resonancia internacional que dicen mucho del poder del imaginario en el afianzamiento de una vocación ${ }^{55}$. En el año 1844 la Biblioteca Imperial de Viena poseía, según estas notas, 300.000 volúmenes impresos y más de 120.000 manuscritos; la de la Universidad de Viena 100.000 volúmenes; la de la Universidad de Atenas "muy cerca de 120.000 volúmenes"... Un año antes fueron hallados en los antiguos archivos del palacio Pitti de Florencia varios manuscritos de Galileo; en 1845 apareció (según recorte de El Heraldo de octubre de ese año que se adjunta) el manuscrito del Rinaldo, poema inédito de Ludovico Ariosto. En 1846 el sultán había dispuesto que "se recogieran y colocasen donde pudiesen ser examinados por los hombres de letras" los manuscritos del serrallo de Constantinopla. Aunque en parte venía a defraudarse la creencia "acreditada de tiempo inmemorial " de que en esa biblioteca "existían un gran número de manuscritos griegos y latinos que el fanatismo ocultaba a los extranjeros", el catálogo de lo ya conocido resultaba fascinante. Amplias avenidas, en suma, para el despierto apetito del bibliógrafo, que pocas veces se vería tan satisfecho, pese a su asiduo rastreo por las bibliotecas públicas y privadas, como con el conocimiento que años después llegó a tener de las riquezas reunidas por B. J. Gallardo en la finca toledana de La Alberquilla. En carta a Borja Pavón de enero de 1865 aseguraba, rememorando: "Asombran el gusto y la incansable laboriosidad de este insigne escritor que yo he tenido ocasión de observar aún más a fondo en su librería de

\footnotetext{
53 En Notas de D. C. A. de La Barrera y Leirado a la "Vida de Cervantes", cit., II, fol. 9. La nota en que se encuentra debió redactarse poco antes de 1864, año en que se concluyeron estos escolios de La Barrera.

54 En las "Notas biográficas acerca de los poetas celebrados por Cervantes en el Canto de Calíope, escritas por D. Cayetano A. de La Barrera", incluidas en Obras completas de Cervantes, II, Madrid, 1863, p. 383. "A cuya calificación [del Ensayo] -prosigue- me honraré siempre de haber contribuido con mi dictamen y voto". Anterior es la alusión a "la obra laureada del Sr. Gallardo a cuya próxima publicación tengo la honra de haber contribuido"; algo posterior el significativo inciso: "el que esto escribe, jurado que fue del tribunal que premió la obra y ponente del dictamen en cuya virtud fue premiada" (Notas de D. C. A. de La Barrera... cit., I, fols. 21 y 2 y 8 respectivamente). 55 Extracto en lo que sigue las paginas (numeradas de la 6 a la 12) que se conservan como Ms. 214171 de la B. N. de Madrid.
} 
Riesgo y ventura de un gran bibliógrafo...

Toledo. Infinidad de sus libros están anotados de su mano". Pocos como La Barrera sabían apreciar con exacto aquilatamiento el valor de piezas excepcionales que poseían algunos de esos "preciosos libros". Cuando en 1859 el sobrino de Gallardo estaba enajenando una parte sustancial de la librería de su tío, La Barrera tuvo ocasión de ver con cierto detenimiento un lote de los comprados por Pascual de Gayangos. Evocó en la carta de junio de ese año la importancia de "un bello ejemplar de las Obras de Herrera, la completa edición de Pacheco, ilustrado con notas marginales de Quevedo"56. Pero ante todo se detuvo en el que hoy pasa por ser considerado el más importante códice del Siglo de Oro español: el manuscrito Chacón. De su nuevo poseedor contamos con una carta poco anterior que ha sido aducida como testimonio de singular interés para la historia del manuscrito. Pero lo cierto es que Gayangos no sólo no indicaba la procedencia sino que llegaba a valorar el códice, ante todo, por su realización material y por una circunstancia de interés relativo: "Días pasados compré los tomos en vitela de las obras de Góngora de que habla Hozes en su prólogo y escribió don Gonzalo [sic] Chacón, señor de Polvoranca. No he visto nunca nada mejor escrito ni con tanto esmero: tiene al margen notas explicativas de localidades de Córdoba y de caballeros avecindados en esa ciudad. Es una alhaja, y aunque me ha costado carilla, vale mucho más de lo que por ella he dado"57. La Barrera, por contra, fue al meollo de la característica excepcional que diferencia al manuscrito de todos los de aquellas centurias. Su comunicación resulta, además, suscribible aun hoy, dadas su ajustada economía descriptiva y su admirable rigor bibliográfico: "Entre ellos [los libros procedentes de la Alberquilla] el riquísimo códice de las obras de Góngora formado por D. Antonio Chacón, señor de Polvoranca, y regalado por él mismo al CondeDuque, escrito en hermosas vitelas: monumento literario-artístico de inestimable valor. El retrato, hecho asimismo a la pluma, puede competir con lo más exquisito de este género. Está repartido el códice en tres volúmenes, folio

\footnotetext{
56 Con posterioridad a La Barrera fijaría su atención A. Fernández Guerra en las notas al margen del ejemplar que había pertenecido a Gallardo, resaltando su interés para conocer el "gusto literario" de Quevedo. Con el título de "Apostillas de mano de Quevedo a las poesías de Herrera" serían publicadas por L. Astrana Marín en Obras completas de Don Francisco de Quevedo Villegas. Textos genuinos del autor descubiertos, clasificados y anotados por [...] Edición crítica. Obras en prosa, Madrid, 1932, pp. 1311-1314.

57 La carta de Gayangos es citada por M. Sánchez Mariana después de trazar la historia del códice gongorino y del conjunto de manuscritos de la biblioteca del Conde Duque de Olivares hasta la muerte del marqués de Heliche (1687): "Perdida la pista de los de Chacón, no volvemos a saber de ellos hasta dos siglos después" ("Las Obras de Don Luis de Góngora reconocidas y comunicadas con él por Don Antonio Chacón: Historia y descripción de los manuscritos", en Obras de Don Luis de Góngora [Manuscrito Chacón], II, Málaga, 1991, p. XI).
} 
José Lara Garrido

menor. Todas las composiciones llevan la fecha al margen"58. Sólo por esta puesta en valor de la cronología compositiva comunicada por Góngora a su amigo Chacón se hace La Barrera merecedor de figurar en los anales del gongorismo decimonónico"59.

En la citada carta de 1865 recordaba La Barrera otras facetas del multiplicado ejercicio de la bibliografía por parte de Gallardo: "Copiaba los códices y los volúmenes impresos cuando no le era dable adquirirlos [...] Formaba catálogos de lo más selecto de las bibliotecas y librerías". El discípulo siguió las huellas del maestro en ambos procederes. Fue más allá que él en la casi compulsiva capacidad para copiar de su puño y letra extensos originales o manuscritos. El facilitar "noticias, libros y papeles" y el generoso franqueo "de cuanto puedo hallar de útil y curioso" a que alude en sus cartas abarcaba desde el simple dato biográfico o la solución de una pesquisa bibliográfica a servir en largas sesiones de amanuense. No le arredraba la avidez de sus peticionarios; antes bien, se apresuraba a descubrirles y laborearles filones de datos. Valga como muestra que entre junio y agosto de 1859 no sólo le remitía a Borja Pavón

${ }^{58}$ La carta de La Barrera permite desestimar el increíble relato, hasta ahora aceptado en ausencia de cualquier otra explicación alternativa, al que dio carta de naturaleza Foulché-Delbosc: "Ce que nous pouvons dire, c'est que D. José Sancho Rayón en trouva un jour les deux premiers volumes dans un puesto de vieux libres à Madrid, et le céda à D. Pascual de Gayangos. Peu après, par un hasard vraiment heureux, Sancho Rayón trouvait, de la même manière le tome III et dernier, qui alla rejoindre les deux précédents" (R. Foulché-Delbosc, "Note sur trois manuscrits des oeuvres poétiques de Góngora", en Revue Hispanique, VII [1900], p. 456). Si en el conocimiento de los manuscritos integri de Góngora fue Gallardo quien "inició la bibliografía moderna del autor del Polifemo" (A. Rodríguez Moñino, Historia..., cit, p. 164) ¿cómo se explica la ausencia de pieza tan sobresaliente en el Ensayo?. Sencillamente porque el bibliógrafo no hacía papeletas de los libros que tenía a mano, y porque Sancho Rayón no quiso dejar huella en las adiciones a aquella obra de su lucrativa correduría en la pignoración de las joyas bibliográficas reunidas en la Alberquilla. Justo comentario el de La Barrera en 1862: "Aquel tesoro ha venido a repartirse en su principal y más exquisito fondo, entre diversos ricos y entendidos bibliófilos" (A. Rodríguez Moñino, Don Bartolomé José Gallardo... cit, p. 262).

59 Nadie en el siglo XIX volvería a fijarse en el Manuscrito Chacón, signo sobremanera expresivo de la lenta incorporación de los códices al conocimiento de la poesía gongorina (Véase el exacto apunte de A. Rodríguez Moñino acerca del proceso entre Gallardo y él mismo, op. cit., pp. 164165). Sólo R. Foulché-Delbosc en 1900 organizaría en una relación por años (que va desde 1580 a 1626) los poemas recogidos en el manuscrito Chacón, haciéndola preceder de estas líneas valorativas: "Nous connaissons maintenant la date à laquelle a été composée chacunes des 423 pièces de recueil; c'est un point d'une importance extrême: l'on ne saurait etudier désormais Góngora sans tenir compte de la liste chronologique suivante, que nous avons dresée d'après les indicatoins du manuscrit Chacón" (art. cit., pp. 472-485). En esas mismas fechas el hispanista copió el manuscrito, y en ese traslado, tras una revisión para la que contó con la ayuda de Alfonso Reyes, se fundamentó el texto publicado dos décadas después. En su prólogo, Foulché-Delbosc insistía en que "uno de los méritos del manuscrito Chacón consiste en que establece la cronología de la obra gongorina, asignando su fecha a cada poesía" (Obras poéticas de D. Luis de Góngora, I, New York, 1921, pp. XV-XVI). 
Riesgo y ventura de un gran bibliógrafo...

extensa copia de la Vida de Pedro de Valencia contenida en el códice Q-87 de la Nacional, sino que le prometió trasladar "cuando tenga más tiempo" parte de "la interesantísima correspondencia literaria que siguieron los diligentes panegiristas y comentadores de Góngora D. Martín de Angulo y Pulgar y el Dr. Salazar Mardones con el cronista F. Andrés de Ustrarroz, que la tenía con todo lo más sabio de España. Consérvase en la Biblioteca Nacional y según he visto ha de contener datos curiosos para la ilustración bibliográfica del ilustre poeta cordobés". Por otra parte, las copias realizadas por La Barrera, además de su pulcritud y limpieza de ejecución, suponían técnicamente un calco al detalle de los más nimios rasgos del original trasladado. Con las palabras que él aplicó a las de Gallardo, eran también sus copias "verdaderos facsímiles"60.

$\mathrm{Al}$ haberse perdido en su mayor parte los materiales de trabajo de $\mathrm{La}$ Barrera no es dado constatar hasta qué punto formó catálogos para su uso personal de las bibliotecas y librerías particulares que frecuentaba. Es un instrumento de documentación cuya presencia como recurso orientativo se transparenta en una obra de la complejidad bibliográfica del Catálogo. Como huella primeriza de lo que debió ser un hábito aprehendido del magisterio gallardiano ha llegado a nosotros el breve catálogo de los manuscritos de interés en la biblioteca de Sebastián de Borbón y Braganza. Contiene trece descripciones escuetas que posibilitaban una posterior localización sin margen de error, y el contenido de los códices (literatura medieval e historia) manifiesta el mismo aliento de Gallardo hacia una bibliografía de amplitud y rigor suficientes para apuntar a la futura historia del "ingenio español"61. En tal sentido resulta ejemplar el catálogo bibliográfico que tuvo el privilegio de reunir los nombres de Böhl de Faber, Gallardo y el propio La Barrera. A la muerte del hispanista alemán en 1836 su biblioteca quedó en litigio legal, resuelto por el ministerio de Gobernación al impedir su salida para Hamburgo, ciudad a la que aquél la había legado en su testamento. Gallardo, que la conocía a fondo, hasta el punto de haber identificado en ella seis volúmenes impresos y un cancionero manuscrito de los siglos XVI y XVII que le habían desaparecido en 1814, tuvo ocasión de disfrutarla a sus anchas en 1843 "durante una temporada que pasó en Cádiz con frecuentes desplazamientos al Puerto de Santa María. Entonces debió de redactar el sumario Catálogo"62. Se trataba, sin duda, de un instrumento

60 Como pormenorizo en mi estudio sobre el Cancionero de poetas varios españoles de los siglos XVI y $X V I I$, al que me referí en la nota 6, a propósito de la copia íntegra contenida en el mismo de las Soliadas de Diego Félix Quijada y Riquelme.

61 "Nota de algunos Ms. de la Biblioteca del Señor don Sebastián de Borbón y Braganza", Ms. 12.942 de la B. N. de Madrid.

62 Sigo la documentada explicación de A. Rodríguez Moñino, Historia..., cit, pp. 17-19. En la breve explicación que abre el Catálogo, y se fecha en marzo de 1862 explicaba La Barrera que Böhl de Faber "tenía, y dejó a su muerte, en Cádiz, su preciosa biblioteca de libros españoles. Legola al 
de trabajo que a modo de exacto prontuario seleccionó y ordenó por materias la parte propiamente literaria de la biblioteca. La precisión del encuadre y la tipología distributiva resultan sobresalientes. Gallardo, más allá de la división por géneros y siglos, ensayó una clasificación de los volúmenes que en ocasiones parece preludiar el esqueleto organizado de una historia literaria. Tal ocurre, por ejemplo, en la épica culta, que dividió matizadamente en Épica sacra, De rebus hispaniae, Orlándica, Histórica varia, Milesiana, Mithológica y Lúdica. Cuando Sancho Rayón le regaló el original de ese Catálogo63, La Barrera debió calibrar fuera de su instrumentalidad práctica como guía del fondo de Böhl de Faber, adquirido por la Junta del Real Patrimonio e incorporado a la Biblioteca Nacional desde 1849, otras calidades heurísticas. La doble selección efectuada sucesivamente por tan expertos conocedores y amantes del libro antiguo español (el poseedor de la biblioteca y el catalogador) conducía a una especie de vademecum antológico. Una guía quintaesenciada que sólo precisaba afianzarse en las descripciones, aclarar puntos oscuros y completar algunas entradas para poder convertirse en una útil bibliografía por materias de la literatura española anterior al siglo XVIII ${ }^{64}$.

Gallardo había realizado una selección de títulos que venía marcada por su conocimiento tan extenso como profundo de la bibliografía española. Todas sus descripciones implicaban, aunque no llegase siempre a explicitarse, una valoración de los ejemplares manuscritos o impresos. Valoración tan sutil, a veces, como la que se desprende de no haber desechado, tras consignar la edición de 1591 de las Diversas Rimas de Vicente Espinel, la existencia de una copia manuscrita ("letra menuda del siglo XVII") que venía a significar la

Senado de Hamburgo; pero nuestro gobierno, con habilidad e interés no frecuentes en el de España, negoció y logró su adquisición en precio de 100.000 reales para la Biblioteca Nacional, de la cual forma parte, aunque hasta el día en colección separada y estantería especial".

63 "Catálogo de la librería de D. Juan Nicolás Böhl de Faber", Ms. 21998 de la B. N. de Madrid. Reproduce su cubierta en fotografía M. Sánchez Mariana, Bibliófilos españoles, cit, pp. 228-229. Gallardo anotó al pie del título: "No copio sino los artículos que me hacen al caso".

${ }^{64}$ Catálogo formado por D. Bartolomé José Gallardo de los principales artículos que componían la selecta librería de D. Juan Nicolás Böhl de Faber perteneciente en el día a la Biblioteca Nacional de Madrid, enmendado y anotado por D. Cayetano Albero de La Barrera, Madrid, 1923. Cito por esta suelta de la serie que se publicó inicialmente en el Boletín de la Real Academia Española de la Historia, LXXXI (1922), pp. 478 ss ; LXXXII (1923), pp. 67 ss , 165 ss y 248 ss. En el citado preámbulo hacía notar La Barrera que el presente Catálogo [...] formado en Cádiz por D. B. J. Gallardo, íntimo amigo de Böhl, me ha sido facilitado por Don José Sancho Rayón. Hubo de escribir Gallardo de memoria las más de sus notas a ese trabajo, y así padeció algunas equivocaciones que he procurado rectificar. He ordenado mejor ciertas secciones, y añadido notas [...]". La Barrera realizó las anotaciones, al menos en parte, después de 1860, dada la remitencia a su Catálogo a propósito de la Propalladia de Torres Naharro (p. 42) Hay otros envíos a uno de sus proyectos más queridos, el Cancionero de poetas varios españoles (pp. 17 y 24). Y se cita un trabajo desconocido del bibliógrafo: "Mis notas al tomo de Obras no dramáticas de Lope de la Bibl. de AA. Españoles" (p. 24). 
Riesgo y ventura de un gran bibliógrafo...

pronta rareza del impreso ${ }^{65}$. Sus comentarios, brevísimos en muchos casos y en algunos hasta de brillantez aforismática, encerraban un cúmulo de certeras críticas y de novedosas precisiones bibliográficas ${ }^{66}$. La Barrera se debió ver incitado a un diálogo de saberes con su admirado maestro. En pocas ocasiones tuvo que suplir del todo la falta de anotación del catálogo original67; escasas fueron también las correcciones a datos erróneos o suposiciones infundadas de Gallardo ${ }^{68}$. La lid bibliográfica se resolvió casi siempre en una colaboración tan estrecha que en el texto de bastantes anotaciones La Barrera llegó a retomar, subsumiendo e indeterminando en el suyo, noticias y apuntamientos de Gallardo. De tan emblemática colaboración resultó un instrumento bibliográfico sobre la literatura española cuya solidez y solvencia quedaba muy por encima de lo realizado hasta entonces. Todavía cuando pudo ver la luz en 1923 atesoraba datos novedosos o estados de la cuestión insuperados. Incluso cuando la maraña bibliográfica ofrecía grandes dificultades como en las ediciones de Francisco de Aldana realizadas por su hermano Cosme, la entrada planteaba ya un germen de hipótesis y las indispensables cautelas que podrían haber conducido a una solución satisfactoria del problema ${ }^{69}$.

65 Catálogo ..., cit., p. 24. Que las Diversas Rimas eran efectivamente un libro raro a la altura de 1642 lo demuestra cierta carta del gongorista rondeño Cristóbal de Salazar y Mardones, recordada oportunamente por G. Haley (en Hispanic Review, XXVI [1958], p. 310).

66 A propósito del Paraíso cerrado de Soto de Rojas indica: "Esta descripción poética del jardín que poseía el autor en Granada falta en la Biblioteca de N. A. ni he encontrado de ella noticia en parte alguna" (p. 17). Gallardo se adelantaba así unos años a la descripción que ofrecerían los adicionadores de Ticknor (Historia..., cit., III, p. 532). Éste aludía a las ediciones de 1611 y 1613 de las Obras de Carrillo Sotomayor(op. cit., III, p. 197) pero sin notar la defectuosa impresión de la primera, "llena de erratas y falta de puntuación (p. 22). En el plano crítico me parecen relevantes la definición gallardiana de la Angélica de Barahona de Soto como "libro singular y único compuesto del Ariosto" (p. 40), o el argumento para desestimar la autoría de Quevedo sobre la poesía de Francisco de la Torre: "Pues aunque es claro que no pueden ser del autor Bachiller de la Torre, llevan mucha ventaja a las poesías líricas del mismo Quevedo" (p. 24).

67 Tras la indicación de que "Gallardo no expresa qué edición era la que Bohl poseía" sigue la referencia de las dos de 1605 de La pícara justina (p. 57); por su cuenta, y a propósito de las obras de la primera, considera necesario diferenciar con sus sinópticas biografías a "María do Ceo con Violante do Ceo, ambas monjas portuguesas" (pp. 28-29).

68 La más contundente aparece a propósito del ejemplar sin portada de la Alegoría del Monstruo español de Miguel González de Canedo: "Añade Gallardo que ésta es obra de principios del siglo XVIII. Si se refiere a la impresión, podrá ser exacto en su aserto, pero la obra estaba ya escrita en 1630, cuando publicó Jacinto Polo de Medina sus Academias del Jardín [...] donde menciona este poema y a su autor al hacer panegírico de varios ingenio murcianos" (p. 41).

${ }^{6}$ Catálogo..., cit., pp. 19-20. En el mismo orden se situarían anotaciones sobre las dos tipos de ejemplares (cor "portada grabada" e "impresa") de las Rimas de B. Leonardo de Argensola (p. 16) o sobre las alteraciones de portada y pie de imprenta en la Flor de Apolo, de Miguel de Barrios ( $p$. 21). En cuanto a las bibliografías completas merecen resaltarse las del Cancionero General de Hernando del Castillo (pp. 4-5) o las Glosas a Jorge Manrique (pp. 9-10), insuperadas hasta los 
Una diferencia esencial marcaba el reparto de cualidades y afanes entre Gallardo y La Barrera. Éste pudo sacrificarlo todo a la labor bibliográfica pero mantuvo siempre bajo control la pasión bibliofílica desbordada del maestro. Sólo en raras ocasiones hablaría el autor del Catálogo "con cierto envanecimiento bibliofílico"70. Por ello, quizás no sea del todo certera su presencia, junto a Durán, Estébanez Calderón, Muñoz y Romero o Fabié, en "la gloriosa falange de bibliófilos nutridos a la sombra de la Desamortización". Cuando La Barrera pudo disponer de bienes propios suficientes para adquirir piezas de valor ya había pasado la oleada originada al ponerse en circulación el "enorme tesoro bibliográfico que poseían iglesias y monasterios"71. En mayo de 1859 hablaba de su "pequeña librería" explicando así su origen: "He alcanzado los últimos años de la edad dorada del Rastro a la cual ha sucedido ya allí completamente la del hierro para los asendereados bibliómanos. Mis libros proceden en gran parte de aquel agotado minero: algunos pocos son de lo caro; en general puede calificarse de colección curiosa y nada más". No se conoce catálogo alguno de la biblioteca de La Barrera ni he logrado localizar el inventario de su testamentaría. Reconstruir un espectro del contenido de la misma a partir de las referencias siempre puntuales a volúmenes por él poseídos en el conjunto de su obra resulta empeño más arduo que productivo. Parece que algunas de las adquisiciones más importantes fueron llevadas a efecto por el bibliógrafo con destino inmediato a algunos de los grandes proyectos que traía entre manos $^{72}$.Así para la refundición con importantes ampliaciones del Catálogo realizó la compra a la que alude en carta de septiembre de 1861: "Con los numerosos y también nuevos [materiales] logrados por mi propio con la adquisición que hice este invierno de unas 400 comedias impresas y manuscritas [...] he aumentado y perfeccionado la obra". Corrobora esta hipótesis la consideración hecha por C. Rosell, en calidad de director de la Biblioteca Nacional, al dar cuenta de que con destino a la misma había sido adquirida la biblioteca de La Barrera. Aunque una parte de la misma hubiese sido vendida con anterioridad (Barbieri, por ejemplo, había adquirido los volúmenes de escritos o recopilaciones del propio bibliógrafo que luego

conocidos trabajos de A. Rodríguez Moñino y A. Pérez Gómez respectivamente, de bien avanzado el siglo XX.

70 En las Notas de D. C. A. de La Barrera y Leirado a la "Vida de Cervantes"..., cit, I, fol. 2 ff.

71 A. Rodríguez Moñino, "Advertencia preliminar" a Catálogo de los manuscritos poéticos ... cit, III, p. 13. La creencia de que toda la centuria decimonónica fue "el Siglo de Oro de la bibliofilía española" está necesitada de matices y distingos.

72 Aunque en un caso, e inicialmente al menos, el proceso pudo haber sido el contrario. En carta de enero de 1865 evoca cómo fue alentado a presentar al certamen de bibliografía de la Biblioteca Nacional el futuro Catálogo "que yo escribía meramente para ilustrar y enriquecer mi colección de producciones dramáticas". 
Riesgo y ventura de un gran bibliógrafo...

regalaría a Menéndez Pelayo) la valorativa del conjunto no semeja estar descaminada: "Otro pequeño repertorio, pues solo consta de dos mil quinientos volúmenes, pero todos escogidos y en perfecto estado de conservación, compró el Gobierno para que enriqueciesen o completasen nuestras colecciones a la señora viuda del difunto oficial de esta casa, D. Cayetano Alberto de La Barrera [...] Las obras que dejó escritas y merecieron honroso lauro, dan suficientemente a entender el género a que pertenecían los libros de su elección. Hay entre ellos ejemplares de ediciones principes, raras algunas, aunque no el conjunto, completo en lo posible de una o más materias determinadas, porque no fue La Barrera uno de esos infatigables acarreadores llamados coleccionistas, que se enriquecen de desperdicios y allegan tesoros con que después viven holgadamente sus herederos y sucesores. Ni su modestia conoció nunca lo superfluo, ni su ambición traspasó jamás el reducido límite de sus necesidades"73.

La Barrera debió aprender de Gallardo los fundamentos del quehacer bibliográfico hasta en los más nimios detalles. Las precisiones que sobre el método de trabajo de uno y otro pueden hacerse no son, sin embargo, comparables. Del maestro se han conservado miles de cédulas, papeletas y extractos; del discípulo no. Por desgracia no pasa de ser un rasgo de voluntariosa semblanza el aserto de que "al igual que Gallardo, su vocación de bibliófilo, a que consagró su vida, hizo que dejara un sinnúmero de papeletas y observaciones bibliográficas, copias y datos de la mayor rareza y utilidad"74. Rastreando las huellas del bibliógrafo en la Biblioteca Nacional pude localizar dos pequeñas muestras representativas de su sistema de fichas con información cruzada de carácter documental y bibliográfico. En una hoja suelta se copia, con destino a la biografía del poeta, este apunte recordatorio: "Entre las Rimas y Prosas de D. G. Bocángel, Madrid, 1627, se halla un soneto cuyo sumario dice Hablando el autor con un retrato suyo que acabó con todo cierto el P. Fr. Agustín Leonardo, religioso de la Merced"75. En una serie de cedulillas conservadas juntas se aprecia el interés por Garcilaso y Góngora. Acerca del primero aparecen una descripción bibliográfica de las Anotaciones de Herrera, una nota sobre la procedencia de los supuestos retratos del poeta, y el siguiente reclamo memorativo: "El códice número 4 de mi librería, titulado Genealogía de los Guzmanes, contiene algunas noticias de Garcilaso de la Vega". La papeleta sobre Góngora es más jugosa, y sitúa a La Barrera de nuevo en la vanguardia de los estudiosos del cordobés. Recoge el resultado de una investigación de archivo con destino, probablemente, a reconstruir la vida madrileña del autor de las

73 Memoria para la Biblioteca Nacional en el presente año, 1874, Madrid, 1874, pp. 6-7.

${ }^{74}$ J. Ma de Cossío, Correspondencias literarias... cit, p. 153.

${ }^{75}$ Corresponde al Ms. 2145910 de la B. N. de Madrid. 
Soledades. Cerrando con el calco de la firma del poeta se da cuenta de la carta de arrendamiento otorgada por don Luis el 22 de mayo de 1623 sobre una parte de la casa de aposento que el rey le tenía concedida en la corte, y que alquila a Domingo Fernández, "oficial de la cocina S. M."76.

Tras la muerte de Gallardo fue creciendo la devoción admirativa de La Barrera y la "afición a sus escritos". Coleccionaba desde opúsculos a los menores rasgos salidos de la pluma del bibliógrafo, incluyendo los versos. En septiembre de 1861 indicaba al respecto a su corresponsal cordobés: "Mucho estimé también las dos composiciones que $\mathrm{Vd}$ me mandó, aunque dudo que la letrilla sea de Gallardo. He tenido ocasión y logrado la de adquirir algunos libros y papeles de este erudito, convenciéndome cada vez más de su incansable laboriosidad". Siendo la de Gallardo una obra tan dispersa llama la atención que además de en los dos tomos primeros del Ensayo (únicos aparecidos en vida de La Barrera) cualesquiera noticias, por escondidas que estuviesen en algún recóndito informe o papel volandero, llegaron a ser sopesadas y aprovechadas por el discípulo. En esto su actividad diverge diametralmente de la mayoría de los eruditos del XIX, que sólo prestaron atención -y concedieron autoridad- a las papeletas reunidas en el Ensayo. Éste más que una cantera de materiales a mano -casi res nullius-era para el autor del Catálogo el punto de partida inexcusable en cualquier investigación de historia literaria. Gallardo casi nada había dejado por escudriñar, y por eso lo normal es que se hubiera adelantado en el manejo de los textos más peregrinos, apuntando incluso en la dirección que quienes yendo tras él creían haber encontrado por primera vez. Así lo confiesa sin reservas en diversas ocasiones La Barrera. Reconoce, por ejemplo, que una composición de fray Domingo de Guzmán había sido publicada por A. de Castro en el prólogo al volumen primero de Poetas líricos de los siglos XVI y XVII, "pero sin apercibirse de que en ella estaban los cuatros versos que Cervantes ha hecho célebres. Yo reparé en esos notables versos, pero antes había reparado el insigne Gallardo, en cuyos manuscritos se ha encontrado una completa copia de la glosa del P. Guzmán con sus correspondientes ilustraciones"77. Lo extraño es que tal zahorí de los libros antiguos españoles hubiese pasado por alto algo de verdadero relieve. Tanto que el hecho pasaba a considerarse una especie de contraprueba, como ocurrió a propósito de cierto apócrifo cervantino, la carta de D. Diego Astudillo, que A. Fernández Guerra se empeñó en publicar en apéndice al volumen primero del Ensayo. "Entre los papeles de Gallardo -indicaba La Barrera- se han encontrado copias sacadas del códice colombino [...] sin indicación alguna de aquel bibliógrafo acerca del probable autor de tan

\footnotetext{
${ }^{76}$ Están reunidas en un sobre que corresponde al Ms. $20245^{38}$ de la B. N. de Madrid.

77 Notas de D. C. A. de La Barrera y Leirado a la "Vida de Cervantes...", cit, I, p. 2c7.
} 
Riesgo y ventura de un gran bibliógrafo...

peregrino rasgo: cosa bien extraña en Gallardo, que tenía hecho un profundo y detenido estudio de las obras y del estilo de Cervantes"78.

Claro es que bajo la capa de rendida admiración con sus ribetes de fetichismo, el insobornable La Barrera terminaba calibrando de diferente manera la calidad de los aportes gallardianos. Muestra expresiva de ello se encuentra en la última gran obra por él concluida: la edición de las poesías de Francisco de Rioja. Como referente de autoridad, pero también como indicador del estado embrionario de la biografía y del conocimiento de los textos antes de sus propias investigaciones, reproduce los apuntes de Gallardo ${ }^{79}$. Una pista prometedora, apuntada por el bibliógrafo en solemne ocasión, era rescatada para revelarse una vez localizado el texto de irritante banalidad: "De las notas marginales al sermón del P. Fr. Juan Félix habló el Sr. D. Bartolomé José Gallardo en la defensa que publicó de la Biblioteca Española de Cortes a principios de 1838. Haciendo mención de diferentes libros preciosos que en ella existían procedentes de los conventos, dice: 'Pues en los sermones ¿qué de especies peregrinas y curiosas no se encuentran? [...] [En el de] Fr. Juan Félix Girón, sobrino del Píndaro andaluz Rioja, bibliotecario de Felipe IV, se leen especies muy curiosas para la biografía de este eminente ingenio, cuya vida y escritos investigan hoy los eruditos con solícito afán. Se ha encontrado, entre los manuscritos de dicho bibliógrafo, copia de los referidos apuntes, que nada añaden de nuevo a lo que sabemos de Rioja"80. Más fértil resultaría otra anotación gallardiana sobre el cartapacio Cisnes del Betis ${ }^{81}$. En un extenso apartado de su estudio reprodujo La Barrera "la papeleta original de Gallardo", que le había comunicado Sancho Rayón, en su "contexto abreviado". Concluyendo entonces que "es sensible que Gallardo no exprese donde vio el [códice] que nos ocupa, en el cual encontramos que existían tres composiciones en décimas, dos de ellas para mí desconocidas y la otra que sólo conozco por su borrador"82. Cuando la investigación parecía cerrarse, la expectativa defraudada se resolvió en el hallazgo de nuevo del manuscrito ilocalizado. Fue una de las últimas alegrías de La Barrera como estudioso del Siglo de Oro, pues debió

78 Notas..., cit., I, pp. 2b7-2c8.

79 "Entre los manuscritos bibliográficos y biográficos de D. Bartolomé José Gallardo se han encontrado los apuntes relativos a Rioja que literalmente copio a continuación (en diciembre de 1861). Es una tira de papel, letra de Gallardo" (Poesías..., cit, p. 104).

80 Poesías..., cit, pp. 282-283.

81 En ella había fijado La Barrera su atención con anterioridad. Al tratar de Arguijo indica: "Entre los apuntes bibliográficos de Gallardo he visto papeleta descriptiva de un antiguo códice, compaginado al parecer por el diligente bibliófilo sevillano don Ambrosio de la Cuesta Saavedra, cuya portada y contenido rezan como sigue: Cisnes del Betis [...] ("Notas biográficas acerca de los poetas elogiados por Cervantes en el Viaje del Parnaso", en Obras de Cervantes, XII, Madrid, 1864 ,p. 326).

82 Códice rotulado Cisnes del Betis, descrito por Gallardo", en Poesías ..., cit., pp. 151-155. 
producirse entre enero de 1872 (fecha del prólogo) y mayo del mismo año (fecha del colofón): "Comenzada ya la impresión de estas Adiciones, una feliz casualidad ha hecho que llegue a noticia mía por diligencia del Sr. Asensio y Toledo el paradero actual del precioso códice titulado Cisnes del Betis, que se conserva en la riquísima biblioteca del Excmo Sr Duque de Osuna [...] Han podido, por tanto, copiarse de él y se estampan aquí las tres composiciones inéditas, en todo o en parte, que de nuestro Rioja contiene. Están escritas en décimas. La primera de ellas es absolutamente inédita; de las otras dos publiqué un imperfecto borrador, existente en el códice M-82 de la Biblioteca Nacional, donde al parecer forman una sola composición"83. La fiel atención a Gallardo pudo rendirle hasta el final excelentes frutos.

\section{La Barrera, un bibliógrafo desubicado en el "hampa" de la erudición decimonónica}

A ojos de uno de sus conspicuos especímenes, el temido Vicente Barrantes (declarado enemigo por más del "difunto Gallardo" y del "Sr. La Barrera"), el mundo de la erudición se regía por prebendas y débitos "entre hermanos y cofrades de esta hampa literaria, que no otra cosa se debe llamar aquí nuestro gremio"84. No aceptar el do ut des como patrón de conducta o negarse a formar parte del cortejo político-administrativo y su engranaje de pagos en privilegios y lucrativos cargos venía a ser como una renuncia a la existencia. Pocos se atrevieron con la resolución de La Barrera a desatender las exigencias del monopodio erudito; ninguno como él, gracias a sus conocimientos y su indomable tesón, pudo soportar un posicionamiento al margen del establisment. Tampoco nadie tuvo que pagar un precio tan elevado.

La fidelidad a Gallardo le exigió, en primer lugar, no contemporizar con quienes iban a ir dilapidando su herencia intelectual y material. Lo indispuso muy pronto con el sobrino de bibliógrafo que tras la "larga testamentaría judicial" había quedado "por dueño de la librería y de la pingüe hacienda de La Alberquilla". En la carta cargada de denuncias y enjuiciamientos que me ha de servir de guía en este apartado, fechada el 26 de enero de 1865 y enviada de forma confidencial ("Reservada") a Borja Pavón, se le dedican unos párrafo sin paliativos. Considerándose "ya de los principales ricoshombres de la imperial ciudad", Juan Antonio Gallardo esperaba recibir por vía matrimonial otra

83 Adiciones a las poesías de Don Francisco de Rioja, en su edición de Madrid de 1867, por el ilustrador de ellas D. Cayetano Alberto de La Barrera y Leirado, Sevilla, 1872, p. VIII. A continuación se publicaron las composiciones en décimas: "No se cansan mis enojos...", "Quiero mi grave tormento...", y "Es tan lento resistir..." (pp. IX-XVI).

84 Tan ilustrativa definición la encuentro en una carta sin fecha a M. Cañete publicada por J. M ${ }^{\mathrm{a}}$ de Cossío (Correspondencias literarias ..., cit., pp. 148-149). 
Riesgo y ventura de un gran bibliógrafo...

apetitosa herencia, único medio de mantener un tren de vida que en parte había alimentado con la venta de los tesoros bibliográficos reunidos por su tío ${ }^{85}$. En esta tarea le había asesorado y servido de intermediario José Sancho Rayón, que como recuerda La Barrera "en lo respectivo al conocimiento, rebusco, avalijo y acomodo de preciosidades bibliográficas salió tan aventajado que pronto llegó a competir con el famoso don Benito Maestre y a merecer [...] el dictado de $E l$ Culebro". Con suma habilidad, Sancho Rayón había conseguido que pasase a sus manos "gran parte de la riquísima biblioteca de Gallardo".

Pero más grave que todo esto resultó para La Barrera la utilización calculada, manipulando sus sentimientos de respeto y afecto a la memoria de Gallardo, que de él habían hecho en el asunto del premio de la bibliografía de la Biblioteca Nacional. José Sancho Rayón y Manuel Zarco del Valle convinieron con el sobrino del bibliógrafo extremeño repartirse a medias la cuantiosa suma presentando al certamen "las obras bibliográficas de Gallardo coordinadas y añadidas". "Juzgaron en consecuencia -prosigue- que yo debía ser un excelente voto en el tribunal que hubiese de examinar la obra cuyo premio se deseaba [...] A su tiempo y cuando yo menos podía imaginarlo halleme con el oficio en que se me conferían tan pomposas investiduras". Sin sospechar nada, sirvió tan oportunamente a los planes previstos con "el examen de la [obra] de Gallardo y el informe sobre ella" que no sólo fue escuchado y aplaudido sino que hasta desde el ministerio lo felicitaron regalándole la Biblioteca de Autores Españoles y la Iconografía de Carderera. Sólo los acontecimientos posteriores le revelaron que su entusiasmo hacia la figura y la labor bibliográfica gallardianas había sido interpretados como una señal de aquiescencia a la trama política con que los nocedalistas distribuían cargos y honores: Con el fin de captar ("catequizar" dice La Barrera) prosélitos "para el bando", entre los cuales "en lontananza" llegó a ser visto ("útil operario de la viña").

Cuando La Barrera se dio cuenta de la maniobra envolvente orquestada en torno a él reaccionó con prontitud y firmeza. Dejó de creer que Sancho Rayón y Zarco del Valle habían actuado en cualquier momento de manera altruista respecto al Ensayo. Al contrario, pretendieron aprovechar la sombra de Gallardo para labrarse un crédito como bibliógrafos y eruditos a todas luces inmerecido. Ni habían trabajado lo suficiente ni de la forma exigida por el modelo al que afirmaban completar: "Las notas bibliográficas de los adicionadores son numerosas y pudieron serlo tres veces más, pero se distinguen a primera vista

85 En la carta de septiembre de 1861 La Barrera se manifiesta distante e irónico respecto a la vida ostentosa del "sobrino y heredero Juan Antonio", dudando ya de sus proyectos respecto a la obra de Gallardo: "Acaba de hacer excelente boda (buen provecho) con una estimable joven de la familia del antiguo intendente del ejército Sr Font. Ha gastado en regalos de boda, vajilla de oro y plata, etc, más de dos mil duros. Tiene intención de publicar la correspondencia literaria de D. Bartolomé; pero dudo que lo realice". 
por lo mondas y peladas: nada de datos biográficos, de estudios, de composiciones íntegras, de juicios críticos". De ahí a la ruptura de las relaciones amistosas había un paso, que se encargaron de efectuar con brusca descortesía la entonces inseparable pareja de jóvenes eruditos. Consecuencia inmediata fue el veto a La Barrera. En el tomo primero del Ensayo no se publicaría la biografía de Cervantes preparada por él a ese efecto. Donde tantos materiales ajenos de desigual calidad vieron la luz, hasta el punto de que el volumen publicado en 1863 ha podido contemplarse como "la aglutinación de la mayor parte de las fuerzas vivas de la erudición decimonónica"86, quedaba excluida una pieza valiosa del cervantismo de esa centuria debida al único discípulo de Gallardo.

La Barrera se refirió al "jesuítico proceder" de Sancho Rayón y Zarco del Valle, relacionando esa actuación con el hecho de haber sido "muy mal recibida la negativa mía en las encumbradas regiones del Olimpo literario". Contó por extenso a su corresponsal la visita que había realizado por sorpresa a la casa del primero el 24 de junio de 1863 sin conseguir una explicación de su conducta. Quedó tan afectado por lo sucedido que no pudo por menos que aludir a ello en diversos lugares de sus investigaciones en curso. Al aparecer el tomo primero del Ensayo consignó: "El que escribe, jurado que fue del tribunal que premió la obra y ponente del dictamen en cuya virtud fue premiada se encuentra en plena desgracia de los Srs coordinadores y adicionadores de ella [...] De la tal desgracia no me cabe culpa alguna; es pura y simplemente un acto de la libre y espontánea voluntad de esos Srs, tenga lo que quiera de indecoroso y decortés"87. Comprendería después que servían a su propia causa, guiándose, como buenos postulantes, por la proximidad del pago prometido: "Rayón ya come turrón meses ha, agregado a la Biblioteca del Ministerio de Fomento. Para Zarco se guarda una barra más exquisita"88.

86 J. M. Rozas, op. cit., p. 26. Las circunstancias que rodearon el rechazo y posterior destino de las Nuevas investigaciones acerca de la vida y obras de Miguel de Cervantes ("título que lleva impuesto por el Sr. Rosell") están explicadas por La Barrera en una hoja preliminar que precede al "ejemplar, formado de los pliegos de capilla "que se encuadernó en Nuevas y últimas investigaciones acerca de la vida y escritos de Miguel de Cervantes Saavedra, I, Ms. 7821 de la B. N. de Madrid.

87 Notas de D. C. A. de La Barrera... cit, I, pp. 2 y 8-2 y 9.

88 No querría empañar la figura de Sancho Rayón, uno de los eruditos realmente beneméritos de esas décadas. Basta repasar la semblanza que de él trazó A. Rodríguez Moñino, "Advertencia preliminar" a Catálogo... cit, III, pp. 12-52. Se limitó a jugar sus cartas en el momento preciso, y fue casual que en el tablajero se encontrase -sin saberlo- La Barrera. Con anterioridad al incidente las relaciones entre ambos parecen haber sido cordiales. Sancho Rayón le había franqueado sin limitaciones su rica biblioteca y facilitado apuntes y papeletas: "A la fina y generosa complacencia del señor don José Sancho Rayón, bibliófilo entendido y laborioso, debo estas peregrinas noticias, y otras muchas de no menor interés, curiosidad e importancia para esta obra" (Catálogo... cit, p. 176); "Mi amigo el Sr. D. José Sancho Rayón [...] no ha cesado de proporcionarme noticias de nuevos autores y de piezas manuscritas e impresas del todo ignoradas a la par que peregrinos datos para las biografías ya conocidas" (Carta de septiembre de 1861). Años después se 
Riesgo y ventura de un gran bibliógrafo...

Detrás de todo ello se encontraba el omnipresente y poderoso Aureliano Fernández Guerra, "hombre con más conchas y escamas que una tonelada de galápagos y sardinas, gran muñidor durante cuarenta años de la erudición, las Academias y la Dirección General de Instrucción Pública"89. Quiso ejercer con La Barrera su acostumbrado y displicente ejercicio de sometimiento, que solía empezar inmiscuyéndose y disponiendo a su antojo de las labores de erudición ajenas. Este primer capítulo se cuenta así en la citada carta de 1865: "Me han ocurrido cosas notables que con la buena licencia de $\mathrm{Vd}$ me atreveré a calificar de sucesos casi oficiales. La cosa es grave y pica en historia [...] En el año de gracia de 1853 hice yo relaciones con el Sr. Fernández Guerra y Orbe (D. Aureliano) [...] han continuado por largo tiempo exclusiva y puramente literarias [...] Me alentó y excitó el D. Aureliano a que yo presentase al certamen mi obra premiada luego en él [...] Comenzada que fue la impresión del Catálogo significó dicho señor su deseo de que yo formase y añadiese en él ciertos duplicados índices y le agregase ciertas farsas por vía de muestra y de curioso adorno. Yo no lo estimé conveniente, y como no me dejo fácilmente dominar y conocí desde luego su carácter dominante, imprimí la obra sin levantar mano y sin hacer esperar ni una hora a los cajistas, y terminada me retraje y abstuve de visitarle por espacio de más de catorce meses. Todo parecía indicar que la amistad había concluido. Sin embargo, no era así".

El que La Barrera mismo llamó "segundo capítulo de la historia" tuvo como preludio el nombramiento de éste para premiar el Ensayo de Gallardo: "De la nuca del subdirector de Instrucción pública sale confeccionado el nombramiento de tales jurados". Tras las felicitaciones y regalos llegaron las tentativas de captación política y lo que era peor a juicio del bibliógrafo: "Se me hicieron en el tono dominante propio de la persona que arriba dejo nombrada insinuaciones literarias a que no podía prestarme en manera alguna". La propuesta era de gran calado: aprovechando la autoridad de La Barrera, un pendant de su Catálogo que comprendiese el "teatro moderno español" hubiera llegado a ser un instrumento de poder cultural y selectiva propaganda muy eficaz. La negativa de La Barrera dio inicio a la estrategia de castigo y aislamiento cuyo origen éste captó de inmediato. Habló con Fernández Guerra refiriéndole por extenso las actuaciones "de sus amigos y colaboradores, observando que procuraba mudar de conversación y contestaba con diplomáticas evasivas". Tras este intento fallido las cosas no habrían pasado a

reanudarían las relaciones, como da fe una carta de La Barrera a Sancho Rayón del 16 de abril de 1872, en que le agradece "la generosa y diligente complacencia con que Vd ha favorecido siempre (y ahora bien recientemente) mis investigaciones y tareas literarias" (Citada por A. Rodríguez Moñino, loc. cit., p. 42).

89 Según el certero apunte de A. Rodríguez Moñino, Historia... cit, p. 89. 
mayores de no promediar otra circunstancia que a la honestidad intelectual de La Barrera resultó insoportable: el infautado pavoneo de Fernández Guerra con el expolio de esfuerzos ajenos.

"He roto las relaciones con el mecenas y colaborador [del Ensayo] D. Aureliano Fernández Guerra [...] En cuanto al rompimiento yo lo he llevado a cabo movido por razones que lo hacían ya inexcusable y forzoso y que son ajenas de estos apuntes"90. En la carta reservada se explicitan $a b$ ovo. En donde había sido excluida su biografía de Cervantes, La Barrera vio una manifestación de arbitrariedad duplicada con el extenso apéndice incluido a trasmano por Fernández Guerra. Éste estaba tan pagado de sus supuestas investigaciones que había anunciado la publicación exenta de las mismas resaltándolas del Ensayo mediante una tirada de "ejemplares aparte con portada especial". Cuando la suelta llegó a manos del bibliógrafo su reacción fue inmediata: "Veo con asombro que aprovechándose el Sr Guerra de todos mis trabajos [...] no se digna citarme. Verdad es que a todos nos deja iguales: allí entre algunas cosas que le pertenecen va envuelto a un andar lo descubierto por y trabajado por D. Justo Sancha, D. C. Rosell, Pellicer y otros, de tal manera que [...] pasará por absoluto descubridor de todo. El vaso estaba ya muy lleno y esto lo hizo rebosar. Seguidamente pedí a dicho señor con una sequísima carta de quince líneas, por medio de mi criada, el volumen que tengo formado de mis artículos y recobrado en el acto cesaron nuestras relaciones". Un ejemplar de la tirada aparte fue encuadernado por La Barrera en uno de sus volúmenes de materiales e investigaciones sobre Cervantes. Antecediéndole colocó una extensa crítica del apéndice que comienza reescribriendo algunos párrafos de la carta: "El Sr. Fernández Guerra [...] recopila con habilidad cuanto se ha conjeturado y descubierto acerca de esta cuestión literaria, sin cuidarse de citar a ninguno de los descubridores e indagadores. Todos quedamos iguales [...] A vuelta de las observaciones ajenas estampa algunas propias: tampoco las señala como de su cosecha, pero todas podrán así parecerlo a muchos de los lectores que, o no despuntan de eruditos o no hayan tenido ocasión de ver ciertos trabajos que, si bien impresos, no han conseguido sino muy limitada circulación". Separando lo expoliado era bien poco lo que se debía a la minerva de Fernández Guerra, y sobre esas "nuevas observaciones" aguzó su escalpelo crítico La Barrera. Un resumen de ellas "guardando el orden mismo en que las expone" dejaba al descubierto la endeble contextura lógica y la inconsistencia documental de tales elucubraciones: argamasa de poca calidad para cubrir los intersticios entre sillares ajenos. La ironía del bibliógrafo se disparó a ráfagas, ya sobre "la perspicasísima vista del Sr. Guerra", ya sobre su proclividad para "decidir rotundamente y ex-cathedra, con pretensiones de infalibilidad papal". En pocas

${ }^{90}$ Notas de D. C. A. de La Barrera y Leirado... cit, I, pp. 2 y 8 y 2 y 9. 
Riesgo y ventura de un gran bibliógrafo...

ocasiones un trampantojo de historia literaria ha sido derribado con la eficacia y prontitud que se desarma una arquitectura efímera. La reflexión final, con sus ribetes de moralidad y aviso, apuntaba a la voltaria conducta de Fernández Guerra, su "actual enemiga con notabilidades literarias o conexionadas con la literatura a quienes antes prodigaba encomios, amistad y favores". Algo de real hay en ella y bastante del deseo de no encontrarse sólo frente al entramado nocedalista91.

En más de una ocasión se ha elucubrado "que con Gallardo de director la Biblioteca de Autores Españoles hubiese sido otra cosa"92. Pero el supuesto implica un ingenuo desconocimiento de las relaciones entre saber y poder que regían en el mundo de la erudición decimonónica. Donde tuvieron carta blanca improvisados estudiosos sin rigor ni criterio, que impondrían inaceptables manipulaciones al editar los textos, y donde se permitió a parvenus de la historia literaria acopiar misceláneas o panorámicas de género y época sin orden ni concierto, quedaron fuera justamente los más preparados y capaces. Ausencia clamorosa fue la de C. A. de La Barrera como colaborador en el "panteón de las letras patrias". No sólo, según demostró su edición de las Poesías de Rioja, sabía cómo enfrentarse a tradiciones textuales de gran complejidad, resolviendo cuestiones de autografía y atribución, hasta fijar la colección más filológicamente correcta de un poeta del Siglo de Oro realizada en el XIX. También estaba dotado de una facilidad más que notable para responder a proyectos de envergadura con el apresuramiento y los cortos plazos que en muchas ocasiones el ritmo editorial de Rivadeneyra imponía a sus colaboradores ${ }^{93}$. Por ello no deja de aparecer como una evasiva airosa la respuesta que dio a Borja Pavón en la carta de 1866: "El deseo que Vd indica, favoreciéndome tanto, de que me encargue de colectar e ilustrar algún tomo de

91 El opúsculo de Fernández Guerra y el examen crítico que le antecede figuran en el volumen facticio Nuevos y últimas investigaciones... cit. En la carta de agosto de 1866 contaba La Barrera a Borja Pavón cómo "el 8 de agosto de año pasado se presentó en mi casa, cuando yo menos podía esperar ni imaginar tal visita después de los antecedentes que Vd conoce, el ilustrador de Quevedo. Pidiome quejas y yo le di las mías [...] me respondió que era yo más soberbio que Lucifer. Quedaron por consecuencia reanudadas flojamente nuestras relaciones".

$92 \mathrm{El}$ aserto de P. Sáinz Rodríguez es aceptado y ampliado por J. M. Rozas, op. cit., p. 28.

93 Aludí antes a la celeridad con que fue redactada la Nueva biografía de Lope. Más de admirar es la prontitud con que realizó La Barrera dos de sus más sólidos trabajos cervantinos. De las Notas biográficas acerca de los poetas celebrados por Cervantes en el "Canto de Calíope" aseguraba así su "diligencia y empeño": "Hice en breves días el prometido trabajo para el cual ya tenía reunidos algunos materiales". Acerca de las Notas biográficas acerca de los poetas elogiados por Cervantes en el "Viaje del Parnaso" explicó igualmente: "Me fueron pedidas por el mismo Sr. D: Cayetano Rosell. Muy gustoso yo que las creía necesarias y deseaba esta ocasión, las emprendí, terminándolas en poco más de quince días". Ambas explicaciones se encuentran en sendas páginas manuscritas colocadas antes de las correspondientes sueltas que fueron encuadernadas en el citado Ms. 7821 de la B. N. de Madrid. 
la Biblioteca de $A A E E$, no puede verse cumplido, porque ni me presto yo a trabajar por encargo, ni las tareas mías pudieran bastar a esa ilustración, aun suponiendo que entre los asuntos que estén en proyecto hubiera alguno de $\mathrm{mi}$ gusto y competencia". Para el conciliábulo de los Hartzenbusch, los Rosell, los Fernández Guerra y satélites menores, La Barrera estuvo siempre bajo sospecha. Y el escaparate más preciado de la erudición histórico-literaria del XIX se accedía o por la vía de un pedigrí político y de cargos oficiales o por la de conversiones tan sonadas como la de un Adolfo de Castro.

Lo ocurrido con el Ensayo de Gallardo y con la BAE no constituyeron hechos aislados. La Barrera sólo fue invitado esporádicamente a colaborar en tareas muy secundarias de anotación biobibliográfica, como si se tratase de un estudioso de rango menor. Pero más grave resultó el cerco de cauciones y cortapisas que el restringido mundo editorial, regido por idénticos mecanismos de control a los relevados, impuso a la aparición de sus grandes investigaciones. Aquellas que "en otro país", como afirmó él mismo de la Nueva biografía, se irían "por su pie a la imprenta" quedaban automáticamente condenadas a la preterición más desoladora. Las quejas y anuncios dramáticos se vinieron a encuadernar con reclamos como los que entrecruzan la Nueva biografía de Lope y las Poesías de Rioja. Si en ésta estampaba la ya comentada disponibilidad de la biografía terminada para cualquier editor que se comprometa a publicarla", en aquella anotó: "Si algún día se publicaran las poesías de Don Francisco de Rioja copiadas de sus originales e ilustradas con la vida del autor, redactada sobre legítimos documentos, con la bibliografía de sus obras, interesantes notas y facsímiles, por D. Cayetano Alberto de La Barrera (Tomo I: Biografía. Bibliografía. Tomo II. Las poesías. Notas. Madrid, 1849-1860) quedará debidamente honrada la memoria del ilustre escritor sevillano y satisfecho el deseo de los curiosos"94. No deja de tener un punto de ironía que fuese Hartzenbusch precisamente el que se refirió entre los escritos "generosamente cedidos al editor" por La Barrera a la edición que "la Sociedad de Bibliófilos Españoles le imprimió (Madrid, 1867) [...] trabajo de gran valor por la copia de datos y el estudio feliz de muchos que allí se atesoran"95. El desamparo del estudioso y lo poco que esperaba obtener a cambio de los resultados de sus fatigosas tareas se transparenta en la carta de agosto de 1866. La labor de más de una década, seis años después de ultimada, iba, por fin, a poderse publicar: "[Aparecerá] a costa de la Sociedad las Poesías de Rioja que tengo años ha copiadas de sus originales e ilustradas por mí con la Vida y Bibliografía del autor, ricas de noticias debidas a mi diligencia. Las regalé en efecto y se están imprimiendo. Agradecida la corporación a este desinterés, me ha inscrito con

94 C. A. de la Barrera, Nueva biografía... cit, I, p. 245.

95 [J. E. Hartzenbusch], Memoria..., cit, p. 13. 
Riesgo y ventura de un gran bibliógrafo...

dispensa de todo gasto en el número de sus socios y acordado obsequiarme con doce ejemplares de la obra". Y eso que era la única excepción feliz a la bancarrota que se cebó con casi todo lo escrito por La Barrera en la última década de su plena actividad investigadora. De poco le valió esta proclama irritante de indigencia: "Yo paso por todo con tal de que se publiquen mis tareas" 96 .

\section{El legado de La Barrera: conservación y pérdida}

Quien maneja cualquier tipo de documentos, colecciones de estudios en marcha $\mathrm{u}$ originales de obras concluidas de La Barrera se da cuenta de inmediato de su singularidad material. Lujosas encuadernaciones encartan los resultados de infinitas sesiones de traslado y puesta en limpio desde borradores o versiones anteriores. Con una letra de trazo y ductus inconfundibles, modelación caligráfica de rasgos inalterables en forma, tamaño y encadenamiento y un calculado ornato (mayúsculas, indicación de cursiva, empleo de tinta roja como reclamo discrecional...) los volúmenes salidos de su pluma constituyen auténticas joyas de un arte ya en declive. Pero el caligrafismo atildado del gran bibliógrafo no era ni un rasgo pintoresco de su carácter ni un excipiente puramente ornativo de su infatigable trabajo. Cumplía, en primer lugar, una doble función práctica, de puesta en orden (y en valor) de las investigaciones ultimadas y apertura (en parte prospección, en parte acicate) hacia las indagaciones en marcha o los puntos que iban a precisarlas. Además, junto a esta finalidad enderezada en cierto modo al propio colector latía con fuerza la idea de salvaguardar para el futuro las colecciones de materiales o estudios y los originales de unas obras cuya publicación se adivinaba enormemente problemática. Las declaraciones prologales sobre intención y límites y las reflexiones sobre modos de trabajo y apoyaturas bibliográficas, indicando además los años de inicio y término (conclusión y abandono) en cada una de ellas, dan la extraña sensación de que La Barrera pensaba en otros tiempos y otras condiciones. Aquellos donde sus labores, calibradas de distinta manera, podrían ver la luz en letra impresa desde originales impecables y perfectamente encuadrados en su biografía de investigador.

Nada que considerara de algún relieve en lo atañente a sus trabajos biobibliográficos o al esclarecimiento de puntos esenciales de su biografía personal e intelectual dejaba de ser trasladado por La Barrera, con su exquisito caligrafismo, a una versión definitiva. Así ocurrió con las notas autobiográficas que pudo utilizar Hartzenbusch sólo en los tres pliegos "copia de trabajo concluido", o con la carta confidencial sobre asuntos de tanta enjundia como la

${ }^{96}$ Notas de D. C. A. de La Barrera y Leirado..., cit, I, p. 2c9. 
denuncia del complot orquestado contra él por Aureliano Fernández Guerra97. Por el mismo proceso de reproducción autografiada pasaron sus libros en su versión definitiva: los manuscritos de la Nueva biografía o de las Poesías de Francisco de Rioja. Los trabajos no ultimados o las colecciones de materiales dejan entrever que dicho proceso implicaba más de un estadio de redacción, con estratos diversos de ampliaciones y sucesivos reeemplazamientos de lo anterior por lo renovado. La Barrera intercalaba a intervalos, adecuando las partes ultimadas o los artículos ya redactados e incluso los impresos a una idea del proyecto definitivo, grupos variables de páginas en blanco. Responden a esta fórmula los dos volúmenes del Cancionero de poetas varios y los otros dos de las Nuevas y últimas investigaciones acerca de la vida y escritor de Miguel de Cervantes. En el primero de estos, un ejemplar de las Nuevas investigaciones publicadas en la edición de las Obras completas de Rivadeneyra "va añadido con nuevas notas manuscritas, en que doy noticia de posteriores indagaciones, insertando algunos importantes documentos"98. El siguiente paso, anterior todavía al traslado final, suponía la redacción en borrador sobre el conjunto de notas de una nueva versión, que pasaba a reunirse a otras del mismo carácter. De esta forma, los originales de La Barrera crecían y se modificaban a modo de dinámicos palimpsestos, tal como refleja el manuscrito de la Notas a la Vida de Cervantes de Fernández de Navarrete. Fechado en 1860, cuando debió terminarse el primer traslado, en febrero de 1863 se agregó con tinta roja la siguiente explicación: "N. B. Estos preliminares y justamente algunos artículos se han rehecho ahora con ocasión de encuadernarse de nuevo el volumen para agregarle considerables y peregrinos aumentos".

Los multiplicados ejercicios de refacción y traslado de sus escritos certifican que La Barrera fue un grafómano de sostenido aliento. Puso las capacidades y habilidades de este orden al servicio de la eficacia expositiva y la actualización permanente de cuanto investigaba, imponiendo también con ello un control selectivo de sus copiosísimos materiales. El proceder encerraba, no obstante, algunos riesgos, y en el ir y venir de los borradores o textos de referencia a las versiones caligrafiadas que pasaban a conformar un nuevo estadio, rara vez cerrado como definitivo, había márgenes para el descuido y el consiguiente error. La grafomanía le jugó al bibliógrafo más de un contratiempo. Particularmente grave y amargo fue el ocurrido con su cuidada

\footnotetext{
${ }^{97}$ La puesta en limpio enviada a Borja Pavón se encuentra en el Ms 19599 de la B. N. de Madrid; el borrador corresponde al Ms 1293913 de la misma.

98 Representa el material en bruto para una posterior redacción, por lo que me parece significativo del método con que trabajaba La Barrera la documentación acopiada. Son cuarenta páginas manuscritas, entre las que siguen quedando varias en blanco, intercalándose algún que otro folleto y documentos fotolitografiados. Las fechas indicativas corresponden a un artículo de $L a$ Iberia (1864) y el fragmento de una carta de José María Asensio (1865).
} 
Riesgo y ventura de un gran bibliógrafo...

edición de las Poesías de Rioja. Cinco años después de publicada por la Sociedad de Bibliófilos Españoles se vio obligado "el ilustrador de ella" a publicar un breve apéndice con el título de Adiciones a las poesías de Don Francisco de Rioja. Su prólogo justificativo se inicia con enigmático énfasis: "Al dar aquí razón del contenido de este pequeño volumen y de los motivos de su salida a la pública luz, diré, cual acostumbro, lisa y llanamente la verdad". Reconoce luego que aunque "ha empleado siempre en esta clase de tareas la más escrupulosa atención, la más atildada y material prolijidad", tuvo al preparar el texto de los poemas de Rioja "un olvido imperdonable". "Concluido que tuve en $1856 \mathrm{mi}$ trabajo bio-bibliográfico relativo de don Francisco de Rioja -evoca- procedí a trasladar las poesías de este eminente ingenio del ejemplar de la colección de D. Pedro Estala en que las tenía ya corregidas por los manuscritos de la Biblioteca Nacional, y formé de ilustraciones y texto dos tomos esmeradamente escritos que después han servido de original para la impresión". Ocho de lo sonetos habían dejado de trasladarse privando al poeta barroco sevillano de una porción notable de sus versos ${ }^{99}$."Advertida por mí la falta -concluye- a los pocos días de haber salido a la luz la obra, fueron desde aquel momento mi constante pesadilla el defecto que la deslucía y el deseo de remediarla en lo posible con la publicación de un apéndice adicional [...] Tales son el origen y el asunto de este reducido trabajo. Espero indulgencia para mi involuntaria falta y me complace en pagar debido tributo de agradecimiento a los eruditos que han honrado con su favorable juicio la edición ilustrada por mí de las Poesías de D. Francisco de Rioja"100.

La calidad material de los volúmenes autografiados por La Barrera ha representado una indudable salvaguarda de su obra. Aunque no pudo evitar la

\footnotetext{
99 Los sonetos se publicaban en las Adiciones con el siguiente orden: "Ardo en la llama más hermosa y pura...": "De los rosados cercos donde suena..."; "Prende, sutil metal, entre la seda..."; "Hiere con saña el mar y con porfía..."; "Estas ya, de la edad, canas ruinas..."; "No se acredita el día, antes se infama...";"¡Cómo a ser inmortal Manlio caminas..."; y ";O rotos leños y mojado lino..." (pp. 1-17). En la Hispanic Society, adquirido de la Librería Hierseman, se encuentran los "dos tomos esmeradamente escritos" por La Barrera (Catálogo de los manuscritos poéticos..., cit., II, pp. 332-338). En el catálogo de la citada Librería se hacía notar ya la circunstancia más sorprendente, al describirlo como "manuscrito original muy curioso e interesante en magnífica letra española a dos tintas que sirvió para la publicación del volumen en los Bibliófilos Españoles con los ocho sonetos que faltan a aquél" (op. cit., pp. 534-535) En efecto, en dicho manuscrito figuran los ocho sonetos seguidos aunque con diferente orden al que fueron luego publicados: seis contenidos en el Ms. M-82 "solo en la copia de las poesías hechas para D. Juan de Fonseca" y dos de otra procedencia (op. cit., p. 336). Como las paginación del autógrafo de La Barrera va seguida y sin alteraciones cabe preguntarse qué ocurrió realmente en la edición de 1867. Caben dos soluciones: o el autógrafo no sirvió "de original para la impresión", sino que se emplearía un traslado en el que se produjo el salto de copia, o bien el bibliógrafo rehizo su original de nueva planta incorporando los textos ausentes. Me parece más verosímil la primera hipótesis.

100 Adiciones... cit, pp. VII-VIII.
} 
dispersión, iniciada en vida del bibliógrafo con el regalo a Asensio y Toledo de El Cachetero del Buscapié y proseguida en su testamentaría con las adquisiciones que irían a parar a las bibliotecas de Menéndez Pelayo y Archer M. Huntington, aseguró su supervivencia. De esta forma el legado de La Barrera, casi perdido por lo que se refiere a sus papeletas bibliográficas, notas de lectura o traslados de documentos de archivo, ha llegado relativamente completo en lo que fueron los resultados últimos de sus investigaciones concluidas o en marcha.

Con una clamorosa excepción: el texto definitivo de su aportación biobibliográfica más conocida y de más vasto aliento panorámico. Con el auxilio de distintos fondos bibliográficos (entre ellos los de la biblioteca que había pertenecido a Gallardo y el extenso lote de comedias impresas y manuscritas adquirido por él mismo), La Barrera procedió, apenas recién aparecido en letra impresa, a completar y corregir su Catálogo bibliográfico y biográfico del teatro antiguo español. En septiembre de 1861 escribía al respecto: "He aumentado y perfeccionado de tal manera la obra que admira el trabajo alemán de notas marginales y pliegos intercalados que ilustran el ejemplar adicionado". Poco antes de presentar el Catálogo rehecho con la Nueva biografía como apéndice al concurso de bibliografía de la Biblioteca Nacional de 1866, recalcaba: "He continuado las adiciones y correcciones a mi premiado Catálogo del teatro antiguo español, ya tales y en tal número que exigen una reimpresión del libro". Tras el desenlace ya conocido de dicho certamen siguió La Barrera laborando en su obra. En junio de 1868, con la esperanza puesta en que la biografía del Fénix fuera el "apéndice que ha de llevar mi Catálogo [...] en su nueva edición aumentada y corregida", indicaba entre sus tareas "la interminable de adicionar el Catálogo y rectificar y enmendar su primitivo texto".

¿Qué sucedió con el nuevo Catálogo? En buena lógica el original debía haber sido entregado a la Biblioteca Nacional a la espera de que las disposiciones presupuestarias hubiesen hecho posible su publicación ${ }^{101}$. Es el camino que siguió su complemento: la Nueva biografía de Lope. Pero una reciente noticia con marchamo de oficial asegura que "no tenemos información sobre el paradero de la obra corregida. El original presentado debió de devolverse a La Barrera para que incluyera las últimas adiciones, según el acuerdo tomado por el tribunal en su reunión definitiva [...] y quizá no volvió a la Nacional"102. La primera parte del supuesto está bien fundada, pero no así su correlato final. La existencia localizada del Catálogo con adiciones a la altura de 1917 y las

101 En la carta de 17 de agosto de 1868 La Barrera comentaba cómo se había dispuesto que las obras premiadas fueran publicándose por orden de antigüedad y que delante de su Catálogo renovado estaban las obras de Gallardo (completar el Ensayo), Zarco del Valle, Aguiló, Escudero y Pedroso y Alenda y Mira.

102 J. Delgado Casado, Un siglo de bibliografía..., cit., p. 238. 
Riesgo y ventura de un gran bibliógrafo...

expectativas que levantaba entonces la posible edición de las partes añadidas quedan confirmadas por A. Morel Fatio: "Le supplément du Catálogo, dont on a annoncé souvent la publication, se fait toujours attendre"103. ¿Será verdad lo que por esas mismas fechas aseguraba J. Cejador, acerca de que el ejemplar adicionado de La Barrera era objeto habitual de expolio?104 Un espeso muro de silencio se ha interpuesto en mis averiguaciones, como si el sino que persiguió al bibliógrafo en vida nunca terminara de alargar su sombra. Todas las pesquisas por mí emprendidas han resultado baldías ${ }^{105}$. Pero resucitar aquí el recuerdo y las pistas conducentes al ejemplar ilocalizado (aunque puede que no definitivamente perdido) acaso sirva de acicate a otras búsquedas. El hallazgo del Catálogo renovado sería un acontecimiento de primera magnitud para la bibliografía y la historiografía literarias del siglo XIX. Nada menos que diez años de la labor más granada y madura de Cayetano Alberto de La Barrera aflorarían con él. Proyectando luz como su punto de partida, el Catálogo de 1860106, no sólo al teatro sino al conjunto de la literatura española del Siglo de Oro.

\footnotetext{
103 A. Morel Fatio, art. cit, p. 117. El rigor del insigne hispanista inclina a pensar que se hacía eco aquí de algo más que noticias inconcretas, aunque no he logrado corroborar con ningún refrendo documental sus afirmaciones.

104 "Asimismo dejó para otra edición del Catálogo del teatro español muchas notas que están en el ejemplar autógrafo de la Biblioteca Nacional: de ellas han sacado algunos varias noticias dándolas por propias" (op. cit, VIII, p. 301). La fiabilidad de este erudito exige cauciones; su insidiosa denuncia, sin dejar de ser verosímil, sólo podría ser certificada de aparecer el Catálogo revisado. En cualquier caso, y pese a la imprecisión de describir como "autógrafo" el volumen completo, alguien tan asiduo a la Nacional y tan buen conocedor de sus fondos como fue Cejador difícilmente fabularía sobre el que consideraba "uno de los libros más eruditos y ricos, indispensable para la historia literaria".

105 He revisado todos los ejemplares del Catálogo existentes en la Biblioteca Nacional, cuyas signaturas son las que siguen: 1/68475, 2/58158, 2/82333, Cat/961, Mss Imp. 547, U/8186, BM "11/17" y R/38060/Aut. Tan sólo éste último contiene unas mínimas anotaciones en las pp. 412, 418 y 476 realizadas por F. A. Barbieri, según se consigna en la firma que figura tras la tercera de ellas.

106 Tan útil instrumento biobibliográfico ha tenido un privilegio excepcional entre las obras legadas por la erudición decimonónica. En el plazo de un año aparecieron dos ediciones facsimilares en sendas colecciones prestigiosas de textos y estudios filológicos: Tamesis Books (Londres, 1968) y Gredos (Madrid, 1969). En ninguna de las dos se consideró para nada la realización por La Barrera de un Catálogo de nueva planta.
} 
José Lara Garrido

\section{APÉNDICE DOCUMENTAL}

[Extracto de las actas, comunicados y órdenes referentes al Concurso de Bibliografía de la Biblioteca Nacional de 1866]

[Archivo de la Biblioteca Nacional, Sig. 0393, Doc. 03].

[I]

Sres del tribunal de premios de la Biblioteca Nacional de Madrid para el concurso de 1866.

Al tener la honra de presentar a ese docto y respetable tribunal, sometiéndolo a su fallo, las adiciones y correcciones a mi Catálogo bibliográfico y biográfico del Teatro antiguo Español, premiado en el certamen del año de 1859, y juntamente, y por Apéndice a las mismas, la Nueva biografía del inmortal Lope Félix de Vega Carpio, escrita por mí con auxilio de preciosos documentos, estimo indispensable acompañar este trabajo con algunas breves advertencias que hasta cierto punto expliquen las bases y el objeto de mi tarea.

Apenas terminada en 1860 la impresión de mi laureado Catálogo, ya tuve ocasión de hacer en la obra correcciones, y de enriquecerla con aumentos y datos de singular interés e importancia. Durante los seis años que desde aquella fecha van transcurridos, al mismo tiempo que con mis propios estudios e investigaciones he continuado incesantemente esas dichas tareas de corrección y aumento, he debido a doctísimos literatos españoles y a eruditos extranjeros que apasionadamente aman y estudian las letras españoles, considerable caudal de documentos y noticias para enmienda de los errores de mi libro, y muy en especial para el acrecentamiento de sus artículos. Si el trabajo que presento, de adiciones y enmiendas, logrando la propia honra que el primitivo llegase a ver la pública luz, yo llenaría cumplidamente y en su lugar oportuno la obligación en que estoy de mencionar los nombres de cuantos me han favorecido coadyudando al perfeccionamiento de la obra a que principalmente debo cierto renombre literario, singulares honras del Gobierno y la estimación y el aprecio de hombres eminentes en el estadio y cultivo de las Letras.

Cuestión ardua será la que, respecto de la publicación de estas enmiendas y adiciones, se ofrecerá en el caso de que por ese digno tribunal sea juzgada como acreedora del premio. No soy yo competente para resolverla, pero sí podré manifestar, que, en mi opinión, el número e importancia de los 
Riesgo y ventura de un gran bibliógrafo...

aumentos y correcciones exigen y reclaman una nueva edición del Catálogo. A pesar de este parecer mío y del intento, conforme al mismo sentir, que me ha guiado en la tarea; si competentemente se determinase reducir la publicación a un Suplemento, yo acomodaré a esa forma especial mi trabajo, siquiera me sea forzoso para ello emplearle muy prolijo, cansado y detenido. En cualquiera de los dos casos se acrecentarán las adiciones con el gran número de ellas que tengo dispuestas y que la premura del tiempo y una peligrosa enfermedad no me han permitido últimamente insertar en el ejemplar adicionado.

Como Apéndice a la obra principal, someto al juicio de ese imparcial jurado la Nueva biografía de Frei Lope Félix de Vega Carpio, que, con presencia de la riquísima colección de cartas del mismo a su Mecenas, favorecedor y amigo el Duque de Sesa, descubierta en el archivo del Exmo Sr Conde de Altamira a principios de abril de 1863; con inserción de gran parte de las que son biográficas $\mathrm{y}$ con nuevos datos $\mathrm{y}$ documentos he redactado prolija $\mathrm{y}$ extensamente. No permitiendo esa misma extensión que la biografía ocupe en el Catálogo, y en su artículo Vega Carpio, el puesto que la corresponde, y ofreciendo por otra parte señaladísimo interés la relación completa y en lo posible exacta de la vida del gran dramático, he creído que tal Apéndice, siquiera forme por sí solo un grueso volumen, acrecentaría en gran manera la importancia y el valor literario de la obra para cuyo complemento le destino, en una edición nueva de ella corregida y aumentada. El tribunal, no obstante, resolverá en este punto, como sobre todo, lo más acertado y asequible; teniendo en cuenta que mi aspiración al premio se funda en el ejemplar impreso de mi Catálogo.

Madrid, 25 de Noviembre de 1866

Cayetano Alberto de la Barrera y Leirado

Encargado por el Sr. Presidente de informar acerca de los dos tomos presentados por D. Cayetano Alberto de La Barrera al público concurso de este año, el que suscribe tiene la honra, después de un detenido examen, de ofrecer al Tribunal el resultado de sus observaciones.

Es el primero de ellos uno rotulado Catálogo Bibliográfico y Biográfico del teatro antiguo Español corregido y aumentado etc, o sea el mismo tomo impreso que 
conocemos, considerablemente adicionado, ya en sus márgenes, ya en sus hojas intercaladas, y presentando además de unas 80 biografías nuevas, o alteradas por completo, un número tal de noticias literarias y datos bibliográficos que podría en rigor ser considerada como obra nueva y distinta, puesto que su primitivo caudal está por decirlo así casi doblado.

El tomo relativo a Lope, gracias al celo y laboriosidad del Sr Barrera, gracias también al descubrimiento recientemente hecho en el Archivo de Casa de Altamira, de una correspondencia autógrafa del Fénix de los Ingenios con su patrono y favorecedor el duque de Sesa -correspondencia que el autor ha tenido la dicha de disfrutar- es un esmerado trabajo en que lucen la profunda erudición, sana crítica, buen gusto literario y otras dotes literarias del Sr. Barrera, constituyendo por sí solo una adición importantísima a la historia de las letras españolas en el siglo decimoséptimo. Porque son tantas las citas e ilustraciones con que la ha enriquecido, y tal el cúmulo de datos históricos que en él ha reunido y allegado, que más bien que Vida de Lope de Vega, el libro parece, y es en efecto, historia literaria de su tiempo; y como por otra parte nuestros mejores ingenios de aquel siglo cultivaron con preferencia el Arte Dramático, resulta naturalmente que los dos tomos hoy presentados por su autor al público certamen forman un rico arsenal de noticias a cual más curiosas y peregrinas para la historia literaria, como lo prueban los copiosos índices que a la obra acompañan.

Ésta, sin embargo, según su mismo autor la intitula y denomina, no es estrictamente hablando más que una serie de correcciones y adiciones a la ya premiada por esta Biblioteca Nacional en el público concurso de 1860. Y aquí entran las dudas del que tiene en este momento la honra de dirigirse al tribunal. ¿Es justo y conveniente premiar por segunda vez una misma obra por más corregida y aumentada que la presente su autor? De hacerse así, ¿no se correría el riesgo de que escritores puestos en igual caso acudiesen por dos o más veces solicitando el premio debido a sus fatigas e investigaciones? ¿Cabe dentro del espíritu del Reglamento que se haga así?

El que suscribe, por más sensible que lo sea en el presente caso declarado, es de opinión que no puede ni debe hacerse. Pero en cambio cree que debe desde luego el tribunal proponer al Gobierno de S. M. la inmediata adquisición de los tomos del Sr. Barrera por la Biblioteca Nacional, y recomendar urgentemente su pronta impresión por separado, devolviéndose a su autor el manuscrito a fin de que pueda oportunamente arreglar su texto; aunque por otra parte, son tantas y tan varias las correcciones y adiciones en ellos nuevamente introducidas, así como las biografías enteramente suprimidas y que habrían de ser reemplazadas por otras, que sería muy conveniente y aun necesario hacer nueva y segunda impresión de toda la obra, como quiera que 
Riesgo y ventura de un gran bibliógrafo...

abultando ya más la materia nueva que la original, resultaría de no hacerse así un tomo algo disforme en tamaño, y de trabajosa y difícil lectura por la abundancia y variedad de noticias que completan, rectifican o anulan del todo el primitivo texto.

Tal es en suma el dictamen del que suscribe. El tribunal con superior acierto determinará lo que sea más conveniente. Madrid 28 de Diciembre de 1866.

Pascual de Gayangos

[III]

Acta de la Junta para la adjudicación de premios celebrada el día 28 de Diciembre de 1866

Reunidos en este día a la hora señalada los Señores que componen el Tribunal nombrado por la Dirección General de Instrucción Pública bajo la presidencia del Señor D. Juan Eugenio Hartzenbusch, leyose por el Secretaria el acta de la Junta preparatorio, que fue aprobada. A seguido diose cuenta del dictamen que entregó por escrito el Sr. D. Pascual de Gayangos acerca de la obra de D. Cayetano Alberto de la Barrera sobre la cual se le había encargado informase en particular, y habida la discusión que se creyó oportuna fue aprobado dicho dictamen, acordando proponer al Gobierno la inmediata adquisición de los dos tomos presentados por el Sr. Barrera y recomendarle con la mayor eficacia su pronta impresión, a cuyo fin se devolvería al autor su manuscrito con objeto de que arreglase convenientemente el texto, sintiendo el tribunal sobremanera no poder adjudicarle el primer premio ofrecido, de que lo consideraba harto merecedor, por la circunstancia de haber sido premiado el mismo autor por la propia obra en el concurso de 1860, si bien en este la presentaba tan notablemente corregida y aumentada que sus adiciones eran dignas por sí solas de igual o mayor premio, y con particularidad el tomo exclusivo de la vida de Frey Lope de Vega. Acerca de ella hizo observar el Sr. Presidente que el afán de ilustrarla hasta en sus menores detalles había llevado a su autor a punto de ofrecer a su héroe con demasiado desnudez, insertando documentos preservados que divulgarían ciertas flaquezas impropias de su alto renombre y más aun del carácter sacerdotal de que se hallaba revestido, por lo que opinaba debían omitirse tales pormenores de modo que no se alterase, sin embargo 
la verdad ni la [escrito sobre una redacción inicial tachada: paliarse de un modo decoroso, sin alterar por ello] la esencia de los hechos, lo que se acordó había de tener muy [hacer] presente para la impresión [...].

Excmo Señor. Cinco han sido las diversas obras, todas ellas de acertada elección, respetable volumen e importancia notoria que ha examinado con la detención posible en el escaso tiempo que señala el Reglamento, el tribunal nombrado por la dirección general de la instrucción pública con fecha de 14 de Noviembre último, para el reconocimiento y calificación de los trabajos presentados al concurso de premios ofrecidos por esta Biblioteca el presente año, y si bien de tan abundante producción deba felicitarse, así el Gobierno como el país y sus intereses literarios, el tribunal tiene sin embargo el sentimiento de no creerse en el caso de proponer ninguna de tales obras, por circunstancias especialísimas, para el primer premio ofrecido.

Cuatro de las obras indicadas aspiraban no obstante a dicho premio, y de merecerlo son sus autores indudablemente dignos; pero a unos habrá faltado el tiempo, a otros la ocasión y los medios de perfeccionar la suya, y a alguno a quien han sobrado y ha sabido ciertamente aprovecharles, lo incapacita, por decirlo así, la consideración de haber sido ya premiado por la misma obra, a la que no puede otorgarse, a juicio del tribunal, nuevo premio, por más que las correcciones y adiciones hechas por su autor bastarían con exceso en otro caso para iguales o mayores recompensas, si posible fuesen, como entiende el jurado que debiera en el presente declararse. Tal sucede con el Catálogo bibliográfico, biográfico del Teatro antiguo español, corregido y aumentado, y la Nueva biografía de Frey Lope Félix de Vega Carpio, que en dos tomos en folio presenta a un tiempo y como complemento ésta de aquél, aunque por separado, D. Cayetano Alberto de la Barrera. El primer tomo es el impreso a expensas del Gobierno por haber sido premiado en el concurso de 1859 pero tan notablemente adicionado ya en sus márgenes ya en hojas intercaladas, y presentando además de unas 80 biografías nuevas o alteradas por completo, un número tal de noticias literarias y datos bibliográficos que puede en rigor ser considerado como una obra distinta, puesto que su primitivo caudal está por decirlo así casi doblado. El tomo relativo a Lope de Vega es un esmerado trabajo en que lucen la profunda erudición, sana crítica, buen gusto y demás dotes de su autor, constituyendo por sí solo una adición importantísima a la historia de las letras españolas en el siglo 
Riesgo y ventura de un gran bibliógrafo...

decimoséptimo, pues son tantas las citas e ilustraciones con que aquél le ha enriquecido y tal el cúmulo de datos que en él ha reunido y allegado, que más bien que Vida del Fénix de nuestros ingenios, el libro parece y es en efecto historia literaria de su tiempo, y como por otra parte los mejores de su siglo cultivaron con preferencia el arte dramático, resulta naturalmente que los dos tomos hoy presentados forman un rico arsenal de noticias a cual más curiosas y peregrinas sobre la materia, como lo prueban los copiosos índices que a la obra acompañan. Ésta sin embargo no es, según su mismo autor la denomina, sino una serie de correcciones y adiciones al trabajo ya premiado, por lo que el tribunal estima lo más justo y conveniente recomendar al Gobierno con la mayor eficacia la inmediata adquisición y pronta impresión de los dos tomos presentados por el Sr. Barrera, a cuyo fin se le deberá abonar una cantidad prudencial y devolver al propio tiempo el manuscrito con objeto de que arregle oportunamente su texto, en el que por acuerdo del tribunal han de omitirse, aunque sin faltar la verdad ni alterar la esencia de los hechos, ciertos pormenores que en la Vida de Lope hace constar su autor llevado del afán de ilustrarla hasta en sus mínimos detalles, pero que ofrecerían al público con demasiada desnudez a este hombre tan esclarecido, divulgando algunas flaquezas impropias de su alto renombre, y más aun del carácter sacerdotal con el que se hallaba consagrado. [...]

Madrid 28 de Diciembre de 1866

[V]

Tribunal de premios

Acta de la Junta celebrada el día 15 de Enero del presente año para acordar la cantidad que deba darse por su obra al Sr. Barrera

Reunidos los Sres que han compuesto el tribunal de premios ofrecidos por esta Biblioteca en el concurso del año anterior, se leyó el acta de la última junta que fue aprobada. A seguido diose cuenta de la resolución comunicada por el Sr. Ministro de Fomento con fecha 18 del corriente aprobando en un todo la propuesta del tribunal y disponiendo que el mismo señalase la cantidad que debe abonarse a D. Cayetano Alberto de la Barrera por los dos tomos que tiene presentados, y habida la oportuna discusión se acordó por unanimidad en vista de los antecedentes que había de otro caso semejante y del mérito singular del 
trabajo del Sr. Barrera se propusiese al Gobierno el abono de los ochocientos escudos señalados para el premio haciendo notar [corregido sobre: indicando], sin embargo, el deseo [dejando al arbitrio del Gob.] de que aun se le diese a ser posible mayor cantidad [...]

Tribunal de premios

Excmo. Sr. Reunido nuevamente el tribunal nombrado en 14 de noviembre anterior para calificar los trabajos literarios presentados al concurso de los premios anuales ofrecidos por esta Biblioteca, en cumplimiento de la Real resolución que V. E. se ha servido comunicarme con fecha 16 del corriente, ha acordado por unanimidad proponer como cantidad que deba darse a D. Cayetano Alberto de la Barrera por la adquisición de los dos tomos que tiene presentados la de los ochocientos escudos que fueron ofrecidos como primer premio, atendiendo a que ya en otro caso anterior se ha dado la misma por una obra no premiada, y en el presente no se satisface ni con mucho el valor real y efectivo de tan concienzudo y esmerado trabajo; pero el tribunal ha creído que tampoco podía excederse de la cantidad señalada para el premio, como hubiera deseado hacerlo y era su deber si pudiese ampliarse a más, lo cual dejo al arbitrio y superior criterio de V. E. Dios guarde a V. E. muchos años. Madrid 25 de Enero de 1867. El Director Juan Eugenio Hartzenbusch

[Al Excmo Sr. Ministro de Fomento]

[VII]

\section{Intrucción Pública}

La Reina (q. D. g.) se ha dignado mandar se adquieran los dos tomos que ha presentado D. Cayetano Alberto de la Barrera por la cantidad de ochocientos escudos, correspondientes al primer premio no adjudicado en conformidad con lo propuesto por VuS. En comunicación de 25 de enero último. La Real Orden lo digo [sic] a VuS. Para su conocimiento y efectos correspondientes. Dios guarde a VuS. Muchos años. Madrid, 6 de febrero de 1867.

Sr. Director de la Biblioteca Nacional 
Riesgo y ventura de un gran bibliógrafo...

[VIII]

Dirección general de Instrucción Pública, Academias y Museo Nacional de Pintura y Escultura

Excmo Sr.

El Exmo Sr. Ministro de Fomento me dice en esta fecha lo que sigue:

«Ilmo Sr: Vista la comunicación del Director de la Real Academia Española, fecha $1^{\circ}$ de Marzo último, solicitando se le permita incluir la vida de Lope de Vega escrita por D. Cayetano Alberto de la Barrera, en la nueva edición que piensa hacer de las obras del Fénix de los Ingenios, S. M. el Rey (q. D. g.) y en su nombre la Reina Regente del Reino, de conformidad con lo informado por la Junta de Archivos Bibliotecas y Museos y de lo propuesto por esa Dirección general ha tenido a bien autorizar a la referida Academia para que haga dicha inclusión».

Lo que traslado a V. E. para su conocimiento y demás efectos.

Dios guarde a V. E. muchos años. Madrid, $1^{\circ}$ de Abril de 1889.

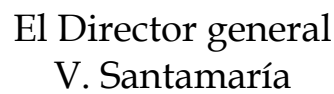

Sr. Director de la Biblioteca Nacional 